\title{
On the Development of the Female Strobilus in Podocarpus.
}

\author{
BY \\ L. S. GIBBS, F.L.S. \\ With Plates XLIX-LIII. \\ INTRODUCTION.
}

$\mathrm{B} \begin{gathered}\text { EFORE starting for New Zealand and Fiji in } 1907 \text {, Professor Farmer } \\ \text { suggested that it would be a good opportunity for collecting material }\end{gathered}$ of the Podocarpoideae, in order to work out the morphology of the socalled 'epimatium', 'aril', or integuments, characteristic of this group. Very little field work soon showed that the study of dried material on which the accepted morphological conception of this family of the Conifers had for the most part been based, had led to conclusions which an investigation of fresh material might considerably modify. Opportunity was therefore sought to collect all available stages in Phyllocladus, Dacrydium, and Podocarpus species. On return a certain amount of work was done which gave valuable data for collecting fresh material on a subsequent expedition to North Borneo in I909.

The results of both collections are embodied in this paper.

In the following table the list is given of the species collected, with localities and dates, and the stages of the ovules on each occasion. It is hoped this will afford some indication to future workers, as to sequence of development.

Material collected when travelling must necessarily be incomplete, and the methods can only be rough and ready. In this case it was mostly fixed in formalin, and subsequently run up in the laboratory to 75 per cent. alcohol, in which, with the addition of some glycerine, it was preserved.

For the youngest stages this process answered very well, but with the growth of the female gametophyte before fertilization the formalin does not penetrate the ovular envelope quickly enough, and a contraction of the extremely delicate tissue of the prothallus results. Dissecting out the nucellus would therefore be the only satisfactory method, but an impossible one to carry out in the field.

[Annals of Botany, Vol. XXVI. No. CII. April, 1912.] 
In the species in which the seed-coat remains unmodified prior to fertilization, in the little material available, archegonia were well shown. On the other hand, in those species which develop a stony layer and show a lignification of the integument before fertilization the material, though excellent for the morphology of the strobilus, was useless for embryological detail.

There is, consequently, in this paper a gap in the sequence of the development of the female gametophyte of the different species described, viz. from the enlargement of the macrospore to the archegonium stage, just prior to fertilization. As far as one can judge from imperfect material these stages seem to agree essentially with what has been observed in other families of the Coniferae.

As soon as embryo formation begins, so much starch is laid down in the prothallus that contraction is eliminated and the stages can be followed.

It will be understood, therefore, that where a point could be substantiated in the embryological development it has been given, in the hope that it may prove of comparative value to future workers, but this investigation is primarily on the morphological side.

The systematic arrangement of the species enumerated in this paper is based on Pilger's Monograph of the Taxaceae in Engler's 'Pflanzenfamilien' series. How far the results of the present investigation modify that arrangement, in the opinion of the author, will be shown at the end of the paper.

A table of the species collected is appended, giving locality, date, and ovular development.

Material collected in Podocarpus, L'Hérit.

- Ovulum, cum carpidio connatum, carpidium ovulum apiculo obtuso superans.'

Sect. I. Dacrycarpus, Endl.

P. imbricata, Bl. Nadarivatu, Fiji. Sept. 1907 .

Archegonial cavity (sterile).

P. imbricata. Singapore, Bot. Gardens. Dec. 1909.

Pollination (sterile).

P. imbricata. Buitenzorg Bot. Gardens. Dec. 1909.

Pollination (pollen-tube). Archegonia, resting oosphere.

P. imbricata. Kinabalu, Brit. N. Borneo. Feb. I909.

Pollination. Archegonial cavity (sterile).

P. dacrydioides, A. Rich. Nihotupu, Auckland, New Zealand. Oct. 1907.

Pollination (pollen-grains). Female gametophyte (free nuclei). 
P. dacrydioides. Te Aroha, near Auckland. Nov. 1907.

Female gametophyte (free cell formation, contracted).

'Epimatium ovuli a carpidio liberum, ovulum carpidium parvum longe superans.'

Sect. II. NAGEIA, Endl.

P. vitiensis, Seem. Nadarivatu, Fiji. Sept. I907.

Nucellus. Pre-fertilization (archegonia initials, contracted).

Sect. III. Stachycarpus, Endl.

P. spicata, R.Br. Ohakune, N. Island, N.Z. Nov. I907.

Pollination (pollen-tube).

Nelson, New Zealand. Dec. I907.

Female gametophyte (free cell formation, contracted).

P. ferruginea, Don. Nihotupu, Auckland, New Zealand. Oct. I907.

Nucellus. Female gametophyte (free cell formation, contracted).

Sect. IV. Eupodocarpus, Endl.

P. elata, R.Br. Nadarivatu, Fiji. Sept. 1907.

Pollination (pollen-tube). Megaspore. Young embryo.

P. polystachya, R.Br. Buitenzorg Bot. Gardens. Dec. I909.

Pro-embryos to young embryo with cotyledons.

$P$. neriifolia, Don. Nadarivatu, Fiji. Sept. 1907.

Pollination (pollen tube). Pre-fertilization (female gametophyte, contracted).

P. bracteata, Bl. Buitenzorg Bot. Gardens. Dec. 1909.

Embryo (root-cap projecting through seed-coat).

P. saligna, D. Don. = chilina, L. C. Rich. Trewidden, Cornwall. April, I9Io.

P. Totara, A. Cunn. Te Aroha, New Zealand. Nov. 1907.

Pollination (pollen-tube). Female gametophyte (free nuclei).

P. Totara. Auckland. Oct. 5907.

Pre-fertilization, bracts already swollen and coloured.

P. Hallii, Kirk. Glade House, Lake Te Ano, New Zealand. March, 1908.

Embryo, cotyledons undifferentiated.

P. nivalis, Hook. Mt. Cook, S. Island, New Zealand. Jan. I908.

Megaspore. Embryo with cotyledons.

In the above table 'nucellus' indicates the homogeneous nucellus of pre-pollination stage, as shown in Figs. 77 and 80, Pl. LIII.

The pollination stage is indicated as 'pollen-grains' when the latter are only seen in the micropylar cavity, or resting on the nucellus, and as 'pollen-tube' when the tubes are penetrating the apex of the nucellus.

In the female gametophyte these stages would correspond to the M m 
differentiation of the megaspore and the first free cell-divisions in the enlarging prothallus.

Pre-fertilization shows the female gametophyte filled with endosperm and archegonial initials, or fully developed archegonia at the apex of the prothallus. In pre-fertilization the pollen-tubes have penetrated the stigmatic apex of the nucellus, and with the male prothallus rest over the apex of the female gametophyte (Fig. 18, Pl. L).

In the following pages, the $q$ inflorescence of Podocarpus is described as a fully organized strobilus, thus following Bennett and Brown (2), Sperk (50), Bertrand (3), and Tison (57). As this point of view has not previously been accepted by the generality of botanists, it is perhaps as well to give a key to homologize familiar terminology in this genus, as given by Pilger in his Monograph, with that used in this paper.

The different parts of the female flower and axis have, up to the present, always been looked upon as so distinct that even portions of the same organ exact different names.

Inflorescence. Female Strobilus.

flower.

Branch in Dacrycarpus, Stalk in Eupodocarpus.

Nageia, and Stachycarpus. Peduncle.

Scales

Scale leaves

Receptaculum

Carpel

$\left\{\begin{array}{l}\text { Epimatium } \\ \text { 'Stumpfer Fortsatz' }\end{array}\right.$,
Scale leaves of the peduncle in Dacrycarpus, Nageia, and Stachycarpus.

Bracts.

Swollen bract bases in Dacrycarpus and Eupodocarpus.

- Lamina of fertile bract.

Lamina of the ovuliferous scale.

Conical apex of the ovuliferous scale (= semicircular ridge of $P$. vitiensis).

By the fertile bract is meant the bract of the strobilus in the axil of which the ovuliferous scale arises.

It must be explained that in Pilger's terminology 'receptaculum' stands for the bases of all the bracts of the cone when subsequent swelling sets in, as is the case in Eupodocarpus and to a lesser degree in Dacrycarpus.

When this secondary swelling does not take place as in Stachycarpus (Pl. L, Figs. 28 and 29), though the bract bases are equally well developed in the young stages (Pl. L, Figs. 25 and 27), in the maturer stages the laminae are caducous, instead of persisting as points as in the two sections above quoted; the bract bases are therefore spoken of as 'scars'.

The 'carpel' is described by Pilger as developing out of one of the scale leaves. That is to say, one portion only, i. e. the lamina, is spe- 
cialized as a carpel. There is, however, no vascular connexion between that lamina and the ovular supplies, and it is difficult to see how the carpellary function obtains either when it is free as in Eupodocarpus, or when fused with the ovuliferous scale as in Dacrycarpus.

This 'carpel' or bract lamina is described as a much reduced and extraordinary small carpel; it is, however, unmodified in the youngest stage in all the sections, even when fused with the lamina of the ovuliferous scale, and does not develop with the ovule, except where there is fusion, and may even be shed entirely, as in $\S$ STACHYCARPUS, before the fertilization stage.

The 'epimatium' or ovuliferous scale is considered to be a ligula-like 'excrescence' of the 'carpel'; but here again the vascular system of the 'excrescence' bears no relation to that of the so-called carpel, but maintains complete independence, even where there is fusion of both laminae (Pl. XLIX, Figs. 8 and 9).

The 'carpel' is also served by one vascular strand only (P1. LIII, Fig. 77) with normal orientation, whereas the 'excrescence' generally shows two (Pl. LIII, Fig. 77), and exceptionally four (Pl. LIII, Fig. 73), all with inverted orientation.

As it is usual to distinguish the sporangium-bearing member in the Coniferae as the ovuliferous scale, that name has been adhered to in this paper.

Pilger's diagnosis for each section is inserted before the description of the species which come under the same, to emphasize better the systematic position, and also for purposes of comparison.

\section{Historical Summary of the Literature.}

The literature on the structure of the strobilus or 'female flower' of Podocarpus is so voluminous, and the views held on the subject so divergent, that it has been thought advisable to give a summary of the principle work on the subject. It is the sum total of this work which is embodied in our knowledge and opinions of the group at the present day.

With one or two exceptions the bulk of this work has been carried out on herbarium specimens, mostly collected in localities not easily accessible and chiefly in mature condition. It is not surprising, therefore, that interpretations based on laborious work on incomplete material should have resulted in many conflicting theories.

As it is desired to restrict this investigation to Podocarpus, all work on the other genera in Taxaceae, where not strictly comparative, has been omitted. This position also applies to all references to the morphological value of the megasporophyll or ovuliferous scale in the Coniferae in general. The voluminous literature on that subject has been admirably summarized by Worsdell (60), and recent investigators disclaim all intention of entering into that vexed question. 
The first species of Podocarpus known to science was $P$. elongata, L'Hér., from the Cape of Good Hope. It was described by Solander in I 788 (49, p. 4I5) as Taxus elongata, Sol.

L'Héritier, in 1807 (31, p. 580), refers this species to Podocarpus, giving the diagnosis as 'Nux ovata, I-locularis, receptaculum firmo semi-immersa'.

R. Brown, in 1814 (11, p. 47), describes Podocarpus as a double cupula, the external one (carpel) forming the drupa, with an aperture near its base or point of insertion. The inner cupula (ovary) is entirely enclosed in the outer one and similarly inverted. He speaks of stigma, style, and fruit.

Richard, in 1826 (41), describes the female flower in this genus as anatropous, the funicle being only slightly indicated. This reversion (p. I25) is due to its being fused for its whole length with a unilateral, fleshy disc, produced at the apex, which corresponds to the base of the flower. This disc may be one of the scales of the involucre, adhering to and forming part of the flower. The pistil is enclosed in a single envelope, corresponding to the calyx, which, however, consists of two portions, an inner one, which thickens and becomes hard, and an outer fleshy one.

Blume, in $1827(5$, p. 88$)$, gives the diagnosis for $P$. bracteata, $\mathrm{Bl}$., as ' Ovarium basi squamula semicinctum. Stigma laterale, sessile'.

Bennett and Brown, in $183^{8}$ (2, p. $3^{6}$ ), in referring to the position of the Podocarpoideae, write: 'The analogy of the scale with that which supports the seeds in the genus Pinus appears originally to have escaped the observation of the elder Richard. It is singular that so unessential a character as the general solitary position of the ovuliferous scale should have induced all the authors who have attempted an arrangement of the Coniferae to separate Podocarpus and Dacrydium from the true Pines and to associate them with the Yew.

'Their true position is in the Abietineae. The inverted ovula bears the same relation to the supporting scale as in the genera of that group.'

Endlicher, in 1840 (22, p. 262), considered Podocarpus as bearing a single anatropous ovule, inserted on a fleshy disc, but later, in 1847 (23, p. 204), he accepts R. Brown's gymnospermous theory, and describes the inflorescence as composed of fertile scales in a lax spike, one or two flowered, the subtending bracts coalescing with the fleshy rachis, their apex alone remaining free. The solitary ovule with two integuments is reversed and sessile near the apex of the fertile scale, with which it is fused in its whole length.

Payer, in $1860(39$, p. 60), describes the female flower as composed of a superior ovary surmounted by a style. This ovary is unilocular, with a naked ovule attached to the base of the cavity.

Eichler, in $1863(19$, p. 430$)$, considered the outer investment of the female flower as an outer integument fused with the inner, and the whole 
flower therefore equivalent in organization to an anatropous ovule. Later: in 1875 (20, p. 62), he accepted Strasburger's 'cupula' theory.

In 1889 (21, p. 46), in the 'Pflanzenfamilien', he describes, without hesitation, (definitely) the seeds in Podocarpeae as anatropous, a funicle being indicated in Podocarpus only; and in this genus two integuments are also present, which are fused together.

Parlatore, in I864 (38, p. I9), considers the $q$ 'amenta' of the Podocarpeae as presenting a similar type of organization to the Conifers. The female flower he describes as reversed and enclosed in two involucres; the inner urceolate, with a circular orifice at the apex, is formed from the upper bracts, the outer from the two subtending bracteoles, which are fused with each other and the inner involucre.

He apparently considers the nucellus as an ovary.

Favre, in $1865(24$, p. 382$)$, pronounces the flower to be an erect anatropous ovule, with an inner and outer integument, the latter penetrated by a raphe, which terminates in an 'expansion chalazienne'. The ovule is surrounded by the two almost completely fused integuments.

Brongniart, in $1866(9$, p. 239), describes the female branch as terminated by three scales fused together for most of their length, of which one bears an erect anatropous ovule.

Carrière, in 1867 (12, p. 644), describes the ovuliferous scales of Podocarpus as naked, or accompanied at the base by a cymbiform bract.

The solitary fruit, inserted on the middle of the scale, or a little below the apex, is free or adnate, broader at the base, with a double integument, the exterior sometimes completely adhering (adnate) to the interior one.

The latter is prolonged in a tube which projects on the outside ("faisant saillie en dehors').

Sperk, in I 869 (50, p. 69), looks upon the structure of the 'stalk' of the flower and the scale into which it merges as partly analogous to the structure of the ovuliferous scale of the Abietineae, with which, as in Podocarpus, there is a fusion of the ovary with the scale, also a reversal of the ovary on all sides. On this scale the ovary is sessile and surrounded by an involucrum, which he designates as a carpel. A difference only lies in the degree of the reversion, that is to say, in the thickness of the carpel ('Fruchthülle').

This difference is explained in the structure of the inflorescence. In Podocarpus there is more play for unrestricted development than in the Abietineae, where the cones exercise a restricting pressure.

Braun, in 1869 ( 7, p. 740$)$, was the first to point out, from a study of an abnormal development of the leaves on a branch of $P$. chinensis, Wall., grown in the Botanic Garden in Berlin, that the so-called receptaculum (Endlicher) or discus (Hooker) of the Podocarps, described as the fusion of fleshy bracts with the axis, is in reality due to the swollen bases of those 
bracts, which become fleshy on maturity, when the free end of each bract can still be distinguished.

Van Tieghem, in $1869(58$, p. 279$)$, is satisfied that the 'stalk' is of foliar structure, the first leaf of an axillary bud which does not develop further.

This 'leaf' is turned towards the dorsal side to form there an anatropous ovule.

Strasburger, in $1872(52$, p. 24$)$, sums up the Taxaceae as being characterized (with the exception possibly of Cephalotaxus) by the absence of true strobilus formation.

The Podocarps are distinct from the Taxaceae in that their flowers occur mostly singly, and, with the exception of Phyllocladus, are more or less fused with the bracts and more or less reversed.

He does not accept the outer envelope of Podocarpus, or the analogous structure in Dacrydium and Phyllocladus, as an integument, but looks upon it as a 'cupula', a sort of discoid proliferation of the axis of the flower.

In $1879(53$, p. 78$)$ he describes the outer envelope in Podocarpus as an arillus, in preference to integument, as it certainly corresponds to the arillus of the Taxaceae. The ovule (p. 79), though resembling an anatropous ovule, cannot be described as such, because the stalk of the latter, the funicle, is always an integral part of the ovule.

In Podocarpus, on the contrary, the stalk, bent over in its apical portion, which bears the ovule, is really the axis of the secondary shoot, consisting of a terminal sessile ovule.

Baillon, in $1873(1$, p. 506$)$ in a concise paper, goes thoroughly into the development of Podocarpus sinensis, Wall., and from the study of the organogeny entirely refutes the anatropous ovule theory.

As he succinctly states, in the ordinary course of development of an ovule with two integuments (to which, so far, no exception is known), the nucellus appears first to be followed by the inner (secondine) and then the outer (primine) integument.

In the case of Podocarpus, however, as he conclusively proves in a series of excellent figures, of these three portions it is the 'primine' which preexists the two other portions ; the nucellus appearing next, and finally the 'envelope' which is thus interposed between the two other parts.

Sachs, in 1874 (45), describes the little flowering shoots of Podocarpus as consisting of a stalk-like axis, swollen above, which bears three pairs of decussate scales.

The axis terminates between the upper pair, the anatropous ovules, with the two integuments (p. 507), being borne in the axils of the second pair, which may be looked upon as carpels, if such are in any way considered necessary.

Bertrand, in 1878 ( 3 , p. 57$)$, describes the ovules of the Gymnosperms 
as always orthotropous, erect in the Gnetaceae, Taxineae, Cupressineae and Cycas, horizontal in the other Cycads and Saxegothaea, reversed in Podocarpus, Pineae, Araucariae, and Sequoiae.

In Podocarpus, he describes the fertile bract as carrying a large ovuliferous scale, which covers, like a hood, a reversed orthotropous ovule with one integument, and which is fused its whole length with the scale.

From the Abietineae to the Taxineae, through Saxegothaea and the Podocarps, he traces a general tendency of the ovuliferous scale to surround, in hood-like fashion, the ovule or ovules which it carries, fusing more and more till finally it merges in the ovular integument in Torreya and Cephalotaxus.

Schumann, in I $\mathrm{I} O 2$ (46, p. 60 ), looks upon Podocarpus as not only distinguished by anatropous ovules, taking the bract at the base as a carpel, but these ovules also possess two integuments, of which it can be determined with 'positive certainty' that the second has arisen from the aril. The sequence of these conclusions is rather involved, and he himself refers to the difficulty in arriving at the same, dried material being alone available.

Worsdell, W. C., in I $900(60$, p. 42), cites Podocarpus as an anatropous ovule which is fused with the bract, and extends far beyond the latter, owing to its being carried up on a long stalk. It has two integuments, of which the outer is fleshy or coloured. In some species the bracts and axis are fused into a succulent whole.

Pilger, in $1903(40$, p. 2), describes the ovule of the Podocarpoideae as reversed, with the micropyle lying towards the base of the carpel, furnished with an 'epimatium', i. e. an excrescence in various ways connected with the carpel ('excrescentia carpidii vario modo connata'). The testa of the seed is formed from the integument and 'epimatium'.

He thus gets over the difficulty of the morphological nature of the protective envelope of the Podocarp seeds, by designating it an organ sui generis, peculiar to the genus Podocarpoideae, consequently of so much importance that the systematic sequence in this group is arranged according to its degree of development. This, through Dacrydium, Microcachrys, and Saxegothaea, attains its maximum in Podocarpus, in which family it is curved and completely fused with the integument.

He considers it incorrect to call the 'epimatium' an outer integument, and so create a contrast ('Gegensatz') to the Pinaceae, which is also the case with the Taxaceae. To describe the ovule of Podocarpus as anatropous is also questionable ('angängig'), as that constitutes an inadmissible ('unzulässig') comparison with the Angiosperms, necessitating a laterally fused funicle, whereas the ovule hangs direct from the 'epimatium', which surrounds it on both sides.

Pilger concludes (p. $3^{8}$ ) that the Podocarps show greater affinity to the 
Abietineae than to the Taxoideae, but defers the discussion of the relationship of the 'epimatium' to the ovuliferous scale of the Abietineae ('Ich muss aber die Discussion dieser Angelegenheiten, besonders des Verhältnisses des Epimatiums zu der Fruchtschuppe der Abietineen, einer allgemeinen Einleitung $\mathrm{zu}$ den Coniferen überlassen ').

Thomson, I905 (55, p. 43), looks upon the female flower of Podocarpus as an anatropous ovule with two well-differentiated integuments, an inner woody and an outer fleshy one.

The fertile bracts are also united in some species to form a 'receptaculum ' which becomes berry-like at maturity.

Tison, in I909 (57, p. I 55), working on Saxegothaea conspicua, Lindl., finds that the so-called aril of earlier botanists or the 'epimatium' of Pilger is really the ovuliferous scale of the other Conifers, the summit of which is developed to protect the ovule, the coalescence of the different parts of the female cone being less than the other genera.

This reduction of the cone is carried further in Microcachrys, where there is less development of the fertile bract above the ovule, whose base is partially protected by the ovuliferous scale.

In the other Podocarps the reduction is much greater, there being only one or two fertile bracts which develop below the ovule, whereas the ovuliferous scale takes on a much greater development, completely encircling the ovule, thus simulating a second integument. Tison recognizes the justice of Bertrand's (3) conclusions.

This view is entirely borne out by the results of the present investigation, which had been already arrived at in 1908, in working out the Fiji and New Zealand Podocarpus material collected in 1907.

Coulter and Chamberlain, I9IO (18, p. 323), describe the ovule of Podocarpus as inverted and stipitate, arising conspicuously above the bracts.

Young, in I910 (61), considers the cone (with the exception of Saxegothaea and Microcachrys) replaced in Podocarpus by the single apparently terminal ovule and a few rudimentary scales. The ovule is provided with an arillus or 'epimatium'.

Finally Brooks and Stiles, in I910 (10), describe Podocarpus spimulosa as anatropous, the nucellus surrounded by two integuments, the inner one being fused for half its length with the nucellus, the outer or 'epimatium' being free from the inner at the micropylar end and on the off-side. On the other it is either not present or fused with the 'stalk'.

In a postscript is added, 'Moreover, however, only on Tison's view can it be considered as proved that the "epimatium" completely surrounds the ovule in Podocarpus.'

They disclaim Tison's results with emphasis. 


\section{Description OF SpeCies.}

\section{$\S$ DACRYCARPUS.}

Flores terminei terminales: receptaculum parvulum, vernuculosum, carpidium fertile unicum, cum ovulo tota longitudine connatum, ovulum breviter apice obtuso superans.

In $\S$ DACRYCARPUS we get a very reduced strobilus, but the most highly organized in Podocarpus itself. The cone consists of a peduncle or 'fertile branch', clothed with scale leaves, terminated by the strobilus of two to four bracts, of which one to three of the apical ones may be fertile.

The lamina of the fertile bract or 'carpel' is fused with that of the ovuliferous scale or 'epimatium', and bears a solitary ovule, medianly placed, on its ventral surface near the apex.

In the sterile bracts the lamineae are long in comparison with those in the other sections, terete, and through not showing secondary development, remain distinct and green.

The bract bases, on the other hand, though unmodified in the early stages, subsequently swell up, fuse, and change colour, the entire surface showing verruculose swellings. Subsequent growth in the ovuliferous scale carries it well above the bract bases, and it forms with the lamina of the fertile bract the whole protective covering of the ovule, which it surrounds and enfolds completely.

\section{P. imbricata.}

Morphology. This species was first described by Blume (5, p. 89) in I 827 . It is figured by Bennett and Brown (2, p. 35 , t. Io) and by Blume $(5,218$, t. I 72, f. 2 et $I 72$ B. f. 2$)$. These plates give a very good idea of the foliage of the tree and its dimorphic habit, and both show the same condition as material collected at Buitenzorg in December (Pl. XLIX, Fig. I), viz. last year's strobilus with this year's above it.

$P$. imbricata is a graceful forest tree, about $70 \mathrm{ft}$. high, with straight trunk and compact crown, occurring plentifully in the mixed montane forests of Fiji, and recorded for New Caledonia, New Hebrides, the Malay Archipelago, and N. Burma. Seen in the virgin forest of Java and on the sheltered slopes of Kinabalu in N. Borneo, the tree assumes a larger size and a more branching and spreading habit, with the crown not so markedly compact as observed in Fiji. It is a true mesophyllous mixed forest type, and occurs always singly. As it runs up the exposed slopes of Kinabalu, however, it is finally, in the sclerophyllous dwarf forest subsummit zone (I I ,500 ft.), reduced to a compact shrub 5-6 ft. high, where, associated with Phyllocladus hypophyllus, Hook., Dacrydium Gibbseae, Stapf, and Podocarpus 
brevifolia, Stapf., it forms one of the chief constituents of that association. There the ultimate branches are erect, the terminal portion showing the cupressoid form of leaves, but arranged radially and five-seriate.

In the mixed forest of lower altitudes the graceful young shoots are always pendulous at the ends of the branches, bearing dorsiventral cupressoid leaves, delicate and light green in colour, and biseriate in arrangement (Fig. I, cup. l.). It is this drooping habit which gives such a pleasing and characteristic 'Taxodium' appearance to the tree. The youth form is characterized by the biseriate leaves, and the ultimate branches are not drooping. This youth form was seen in Fiji up to $10 \mathrm{ft}$. high, the axis of the stem and of the branches being alone clothed with the imbricate leaves. These two forms of leaf are distinct in anatomical structure, the cupressoid being characterized by groups of idioblasts in the mesophyll.

The strobili terminate small lateral peduncles, which arise in the axils of the imbricating foliage leaves of the stem. These peduncles, bearing only imbricating leaves, are curved just below the strobilus in the younger stage, but straighten later (Fig. I, strob. I and 2). The leaves subtending the strobilus pass gradually into the bracts of the latter and spread out round it in both the Fijian (Fig. 4, s. l.) and Buitenzorg material (Figs. I and 3, s.l.), though not in that from the subsummit zone of Kinabalu (Fig. 7, s. l.).

The strobilus, as far as seen, may consist of two to four bracts (Figs. 4, 5 , and 7) of no specific arrangement; the laminae of these bracts are long and terete, the bases swollen and verruculose.

Pilger (40, p. I5) describes the 'receptaculum' in this species as formed of two bract bases, of which the lamina of one is fertile. Where there are two bracts to the strobilus, they are apparently opposite (Figs. 3, 7, and 8); and usually one is fertile, as Pilger describes, but twice in the limited material collected both have been found fertile (Fig. 2), and Blume (6) describes two, and rare cases of three being fertile. In the present case (Fig. 2) the two fertile bracts oppose a dorsal to a ventral surface, instead of a ventral to a ventral surface.

This suggests that the opposite position is one of convenience, due to the exigencies of packing, and that the bracts really continue the spiral arrangement (Fig. 4) of the scale leaves of the peduncle, as these show a gradual transition from the small leaves clothing the peduncle to the larger ones immediately subtending the strobilus (Figs. 3 and 7). This transition is not so marked in later stages (Fig. 4) as the relative difference in size is masked by the growth of the strobilus; but it shows a resemblance to Saxegothaea as figured by Norén (36) and Tison (57, P1. IX, Fig. 7).

The lamina of the fertile bract is fused with the ovuliferous scale (Figs. 6 and 8) to the apex of the latter. The apex of the lamina in the very young stage is quite free and distinct (Figs, 2, 7, and 8). In one case it projected far above the scale (Fig. 3, lam. f. br.). In later stages it may 
persist as a point (Fig. 4, lam. f. br.) or become quite merged with the tissue of the ovuliferous scale (Fig. 6, lam. f. br.).

Histology. In a longitudinal section of a strobilus in the gametophyte stage (Fig. 8) the lamina of the bract is seen to have the apex quite distinct with two lines of stomata. A single normally orientated vascular bundle, starting from a plate of tracheides under the epidermal tissue, runs down the whole length of the fertile bract to the swollen base. It is accompanied by a resin canal with well-developed epithelium (Fig. $8 c, e p i$.) on the dorsal side. A well-marked cuticularized epidermis with a hypodermal sclerotic layer (Fig. $8 a, h . f$.) covers the lamina of the bract, and is continued uninterruptedly round that of the ovuliferous scale.

This sclerotic layer is also present in the foliage leaves of both cupressoid and imbricate forms, being only interrupted by the stomata, which occur in four rows, two on the ventral and two on the dorsal faces, and seems limited in Podocarpus to § Dacrycarpus. Thomson (56, p. 349) records a hypodermal sclerotic layer for the megasporophyll and the vegetative leaf of Microcachrys.

The swollen base of the bract is limited by the verruculose outgrowths (Fig. $8 b$ ) which densely cover this portion. They may also characterize the base of the ovuliferous scale (Fig. 5), which is modified like the bract bases, fusing with them completely. This figure is taken from a strobilus on a tree in the Singapore Botanic Gardens, which was covered with young cones in December. Mr. Ridley informed me that this tree never set seed. The ovules proved all sterile, showing no proper nucellus formation. The epidermal layer of these bract bases is cuticularized, and the cells show dense tannin contents like those of the lamina, but there is no hypodermal sclerenchyma. The other cells are thin-walled, large, and practically devoid of contents. They suggest water-storage tissue, and this may possibly be the function of the so-called swollen 'receptacle' throughout the genus. This tissue is well developed, as we have seen, in post-pollination (Figs. 2, 3, 4, and 7), and increases in size with the growth of the ovule, the increase being due to proliferation of the mesophyll cells.

The structure of the sterile bract resembles that of the fertile. The lamina shows a cuticularized epidermis and hypodermal fibrous layer, and the vascular bundle terminates in a group of tracheides and is accompanied by a resin canal with epithelium. The swollen base is equally verruculose. These swellings are characteristic of $\S$ DACRYCARPUS and possibly increase the surface of the water-storage tissue, which is much less developed in this section than in $\S$ EUPODOCARPUS, and is entirely absent in $\S$ NAGEIA and $\S$ STACHYCARPUS.

The ovuliferous scale completely encloses the ovule, and is fused with the integument throughout its whole length, except in the region of the micropyle. It shows the same structure in its epidermal, hypodermal, and 
mesophyll tissues as the lamina of the bract. Most of the cells of the mesophyll show tannin and associated starch contents, and many also are packed with starch.

The vascular system consists of two bundles with inverse orientation, each accompanied by a resin canal with epithelium. They unite to form a ring at the base of the ovule, but separate again and remain distinct to the base of the bracts, where the bundles run with normal orientation on to the ring of leaf-traces of the strobilus.

This converse orientation is effected by the rotation of the two bundles as they descend the scale, where they form an arc, the phloem gradually diverging outwards and the xylem converging towards the centre (PI. LII I, Fig. 77).

This rotation increases in the passage down the bract bases, until the two bundles run on the ring of collateral bundles of the strobilus, one on each side of the strand of the fertile bract, with normal orientation. The ovular supply bundles in Saxegothaea, as figured by Tison $(5 \%, \mathrm{Pl} . \mathrm{X}, \mathrm{D})$, insert themselves with a similar semi-rotation on to the single vascular strand of the fertile bract, but in Podocarpus the bundles remain distinct.

The integument stands out well from the tissue of the ovuliferous scale, owing to its smaller and more regularly arranged cells. At its free portion, which forms the micropyle (Pl. XLIX, Fig. 8, o.s. int.), the epidermal layer of cells is densely filled with starch and tannin. In the free apex at the micropyle the sub-epidermal cells are strongly lignified, staining with safranin, are pitted, showing spiral thickening, and elongated in a vertical direction (Pl. LI, Fig. 58, a.). This feature is characteristic of all the species examined. The base of the integument is well defined by a zone of nutritive cells. Of these cells some are packed with starch, while others contain both starch and tannin, the starch grains showing up conspicuously with iodine, by their blue coloration, through the tannin (Pl. XLIX, Fig. 8, tan. and st.c.). A similar zone occurs at the base of the nucellus, a fact Tison has also recorded for Saxegothaea (57, p. I44), designating them 'cellules tannifères '; but he does not specify the presence of starch. These cells appear to be initiated at the same stage in both genera, viz. at pollination, with the enlarging macrospore; but in Podocarpus, in conjunction with the zone at the base of the integument, their number increases with the growth of the female gametophyte until starch formation is initiated in the prothallus. Saxton $(44$, p. 559) in Callitris mentions, in relation to the absence of any kind of tapetum in that genus, that 'physiologically its place is taken possibly by the basal part of the nucellus, the cells of which are densely packed with contents'. He further adds that growth of the nucellus takes place mainly in this basal part. This also holds for both integument and nucellus in Podocarpus. 
The mucellus is much contracted in all material at this stage (Fig. 8, muc.), but pollen-tubes can be traced in the apex, whose development, judging from other material, would coincide with free nuclear division in the female gametophyte.

In Fig. 6 a longitudinal section of the ovule in the archegonium stage shows the lamina of the fertile bract no longer so distinct, it having elongated and stretched with the growth of the ovuliferous scale; it is served by one bundle with normal orientation arising from a hypodermal group of tracheides. The mesophyll cells show lignified thickening of the cell-walls, reacting to phloroglucin (Fig. 6 c). This lignification is also seen in the mesophyll of the ovuliferous scale, in which the two vascular bundles, on expanding in a ring round the base of the ovule, send secondary branches into the lamina of the scale. This development, which marks a later stage than shown in Fig. 8, extends half-way down the lamina which surrounds the ovular tissues (Fig. 6, in. v. b. o.s.).

The nutritive cells of the integument and mucellus show considerable increase in number (Fig. 6, tan. and st. c.) and the micropyle is closed, a result effected by proliferation of tissue in the basal portion of the ovuliferous scale and the elongation of the lamina of the same. The integument shows slight peripheral lignification of the cell-walls.

The cells of the stigmatic apex of the mucellus show dense starch contents. Stopes and Fujii (51, p. I I) note in Pimus the deposition of starch in considerable quantities in the tip of the nucellus, in very young ovules in which archegonia were not present. This is also the case in Podocarpus (Fig. 6, nuc. st.). Starch is initiated with the formation of the macrospore, and its presence is no doubt related to the growth of the pollentubes, which, however, do not absorb it entirely, as some is generally present even when the nucellus itself is reduced to this apical portion, which persists as a cap to the prothallus (Pl. L, Fig. $3^{8}$, nuc. cap.). The periphery of the nucellus is marked by large cells with very little contents, whereas the two or three parietal layers of smaller tabular cells which surround the female gametophyte, and are constantly being absorbed by the growth of the latter, show large and active nuclei and denser staining contents, forming a well-marked tapetum.

Coker $(15, \mathrm{p} .103)$ in $P$. coriacea records the complete absence of any tapetum and 'spongy layer', but in the present investigation it was found in every species from the earliest stages till the laying down of starch in the prothallus and in embryo development.

The female gametophyte has increased at the expense of the nucellus, and in this stage contains five archegonia. These are situated at the apex of the prothallus, and are very long and attenuated, each being surrounded by a well-marked jacket layer of denser staining cells with large and active nuclei. Archegonia are separated from one another by sterile 
prothallial tissue (Pl. XLIX, Fig. 6, arch.), and are long and tapering, similar in shape to those described by Lawson in Sciadopitys verticillata (30, p. 413$)$, and in Cephalotaxus Fortunei by Coker $(17$, p. 5). All the five archegonia are in the maturation stage, when according to Blackman (4, p. 404) the uniformly reticulated nucleus increases enormously in size and moves into the centre of the egg (Fig. $6 a, e . n$.) Lawson (30, p. 44) describes the same result in Sciadopitys verticillata, where the egg nucleus enlarges enormously and moves down to the centre of the cell. The protoplasm of the archegonia is much vacuolated, and contains densely staining proteid bodies.

As far as could be ascertained in the scanty material available the necik cells (Fig. 6 a, n.c.) consist of two to six cells. Coker (15, p. 98) gives them as from two to twenty-five in $P$. coriacea. Below the archegonia there is a central cylinder of small-celled tissue (Fig. 6, cen. cyl.) which Coker has also described for $P$. coriacea (1. c., p. 96). The cells of the prothallus are mostly binucleate. Saxton $(36$, p. I75) records in Widdringtonia that this binucleate condition in the prothallus is initiated on the maturation of the oosphere. The cells increase in size towards the periphery, which is limited by an epidermal layer of small uninucleate cells with denser staining contents. This modified epidermal layer, which remains almost free from starch, is characteristic of all species examined (Pl. LI, Fig. 39 b). Coker (15, p. 97) has described a similar layer for P. coriacea, and suggests that it is modified for secretion and correlated with the absence of a spongy layer in that species; but in all the Podocarpus material examined in the present instance, well-marked 'spongy tissue' or tapetum was invariably present.(Pl. LIII, Figs. 74 and 75) in conjunction with the differentiated epidermal layer. Pl. XLIX, Fig. 6 shows the prothallus contracted on one side, due to imperfect fixation, the tissue being so very delicate before starch formation is well under way. Contraction is also seen between the necks of the archegonia, where the tissue often becomes folded by pressure and projects, forming a point at the apex of the gametophyte (Pl. L, Fig. 37). This contraction, in microtome sections, often gives the appearance of the archegonia lying in pits.

The prothallus is surrounded by a delicate two-layered megaspore membrane, of which the fibrous layer turns yellow both with iodine and chloro-zinc iodine. The whole membrane can be dissected off the prothallus in its entirety.

In every species examined a megaspore membrane was found to be present. This membrane is conspicuous in microtome sections, taking a mauve-red colour in gentian violet and Bismarck brown (Pl. LIII, Figs. 74 and 75), and staining red in safranin when dissected off. It resists the action of iodine and sulphuric acid, but in every case responded to the iron sulphate test for tannin. 
Coker (15) records no megaspore membrane for $P$.coriacea. Thomson $(55, \mathrm{p} .42)$ in $P$. coriacea remarks on the absence of this membrane in the early embryo stage, and also in $P$. Mokoyi in mature condition, and questions if the coat is present in the earliest stages. He concludes that Dacrydium, in which the megaspore membrane is well developed, must be much more primitive than Podocarpus from the supposed absence of this feature of the latter (1. c., p. 54). In the present case it has been seen in normal development in every species examined, which suggests that $P$. coriacea is an exception in the order in this respect, as it is also in the absence of a tapetum.

The one prothallus available from Fijian material, dissected out of a normally developed strobilus, proved to be sterile. A cavity immediately above the small-celled central cylinder replaced the archegonia. No tracheides occurred in this tissue, in which the cells were two to four nucleate. The larger peripheral cells were uni- to binucleate and contained very few starch grains. There were, however, many tannin cells, which was not the case in the one described above, from Buitenzorg.

A sterile prothallus from the subsummit zone of Kinabalu (I I,500 ft.), dark brown in colour on the surface, showed on sectioning almost every cell with tannin contents, the central cylinder being alone excepted.

In another prothallus, of which the name of the species was lost, seven archegonia were present, two being in one jacket (Fig. 6 b). In this case there was no contraction of tissue, and the archegonia lay with their necks plane to the apical surface of the prothallus in two distinct groups.

\section{Podocarpus dacrydioides.}

Morphology. This species, familiarly called Kahikatea or White Pine, is a well-known New Zealand tree. In this list. it is the only species which grows gregariously, forming dense forests in swampy localities, and predominating along river beds, where, before the usual drastic clearing on so-called 'settlement', it must have been a valuable agent in fixing shingle banks, which now spread unrestricted over miles of country. In the mixed forest it takes its chance with the other members of an association, in which no one species seems able to prevail. It is a slender tree, with the straight trunk and the small conical crown so characteristic of the New Zealand mixed forest type. According to Cheeseman (14, p. 65I) the tree may attain the height of I5O feet, and he describes the wood as straight-grained and easily worked, but not durable if exposed to damp. It is general in lowland forest through the three islands.

The young strobili are very abundantly produced in October and November. They are minute, but conspicuous from the waxy bloom 
which completely covers them, and are borne on peduncles about $5 \mathrm{~mm}$. long, which may either terminate a shoot, as Tison figures for Saxegothaea (57, Pl. IX, Fig. 6), or they may form little lateral branches, as in P. imbricata. The peduncle is clothed with imbricating scale leaves (Fig. Io, s. l.), of which those immediately subtending the strobilus are larger and more spreading (Figs. IO and II, s. l.).

The bracts may be two (Fig. II, brs.) or three (Figs. Io and 12), with long terete free laminae, which remain erect or open out. The swollen bases are verruculose as in $P$. imbricata. There is one fertile bract, the lamina of which is fused with the ovuliferous scale to the point of insertion of the ovule (Figs. 9, 10, and 13). The extreme apex of the lamina is more or less free in the younger stages (Figs. 9 and 10), but becomes completely fused as growth continues (Figs. I2 and I3). Fig. IO is in the pollination stage.

Histology. A longitudinal section of the ovule shows the lamina of the bract with its normally orientated vascular bundle ending in a group of tracheides (Fig. 9, v.b.br.). The epidermis and hypodermal sclerotic layer is continuous with that of the lamina of the ovuliferous scale as in P. imbricata. The hypodermal layer, as in that species, also characterizes the foliage leaves, where it is only interrupted under the stomata which occur in four lines, two on each surface of the leaf. This layer is recorded by Van Tieghem (59) for the leaves of both these species. The inverted vascular supply of the ovule runs down the ovuliferous scale in two bundles, as previously described, forming a ring round the base of the nucellus (Figs. 9 and $\mathrm{I}_{3}$ ), but in $P$. dacrydioides they were not seen to send branches into the lamina of the scale. These bundles run separately, as in P. imbricata, to the base of the bracts, gradually rotating as they descend, till they insert themselves normally on to the ring of bundles of the strobilus. They are each accompanied by a resin canal with epithelium. These canals, in the region of the ovule, limit the tissue of the integument from that of the ovuliferous scale (Figs. 9 and $\mathbf{I} 3, r . c$.$) .$

Pilger (40, p. 23) describes the upper portion of the integument as being very thin in this species and the large resin canals as lying in the outer seed-coat ('äussere Samenschicht'), presumably the 'epimatium', i. e. lamina of the ovuliferous scale. In the younger stages (Figs. 9 and I 3 , r.c.) it will be seen that there is nothing abnormal in the texture or size of the integument or the position of the resin canals, which are, as Pilger states, very large in this species.

The integument shows the usual differentiation of cells, those in the region of the base being marked by starch and tannin contents which also characterize the epidermis of the free apex at the micropyle (Pl. LIII, Figs. 77 and 78 ).

The nutritive zone of tannin cells is present at the base of the nucellus, 
and the stigmatic surface of the apex shows pollen-grains lodged on it, and the cells dense starch contents.

The megaspore cell divides about the time of pollination, as described by Miyake in Cunninghamia (34) and by Miyake and Yasui in Pseudolarix (35). It is limited by the slightly cuticularized megaspore membrane (Pl. XLIX, Fig. 9, m.m.) and shows nuclear division. The cells of the nucellus surrounding the female gametophyte form two or three tapetal layers of smaller rectangular cells with denser contents and more active nuclei, which are constantly being absorbed by the growing megaspore (Fig. 9, tap.). In an older stage (Fig. I3) where the female gametophyte is much enlarged, filling the centre of the nucellus, the former is too contracted to make out the exact stage, but no cell-walls can be traced in the endosperm, which is definitely outlined by the megaspore membrane. Starch and tannin are present in the cells of the stigmatic apex of the nucellus. The tapetum, showing disintegration of cells, limits the cavity formed by the prothallus. The usual nutritive region of tannin and starch cells is seen at the base of the nucellus and of the integument (Fig. I3, tan. and st.c.).

\section{$\S$ NAGEIA.}

In $\S$ NAGEIA and $\S$ STACHYCARPUS, in the species described, the cone consists of a peduncle, or so-called 'fertile branch', clothed with scale leaves, and succeeded by six to eight strap-shaped bracts, of fleshy consistency, with their long bases fused with the axis.

The apparent opposite and decussate arrangement of the younger stages is subsequently lost on elongation of the axis, as the bract laminae are shed before fertilization, leaving only scars which show a spiral sequence.

The strobilus organization is therefore limited to the younger stages; there is no secondary modification of the bract bases, so that the 'receptaculum' is described as not being developed.

\section{P. vitiensis.}

$P$. vitiensis was provisionally placed in $\S$ NAGEIA by Pilger $(40$, p. 59) on the strength of its vegetative leaves being opposite and broad towards the base. He admits that the leaves are narrower than those of the other species in this section, also that the $\sigma^{7}$ flowers do not agree. The $f$ flowers were unknown to him and are now described for the first time.

In a former paper $(26, \mathrm{p} .182)$ the position of this species in $\S$ NAGEIA is questioned, and its inclusion in $\S$ STACHYCARPUS suggested, from the similarity in habit and in the position of the $\sigma^{7}$ and $q$ flowers to $P$. ferruginea. On anatomical investigation the leaves in $P$. vitiensis were found to possess one vein, whereas it is one of the distinguishing features of $\S$ NAGEIA that in that section alone the leaves are pluri-veined $(40$, p. 5$)$.

In the strobilus, however, the stone cells, which according to Pilger 
(1. c., p. 23) are peculiar to $\S$ STAChyCaRPUS (P1. LIII, Fig. 75) in the seedcoat, proved absent in $P$. vitiensis.

The peduncle of $P$. nagi, as figured by Pilger (40, p. 6I, Fig. D) and in material examined at the British Museum, is thick and shows scars, suggesting a resemblance to older stages of $P$. vitiensis (P1. XLIX, Fig. I6), but it is difficult in this group to draw conclusions from dried or mature material.

The branching of the peduncle, so accentuated in the Fijian plant (Fig. I4), is also to a certain degree represented in $\S$ NAGEIA.

It is therefore thought advisable to follow Pilger, and leave $P$. vitiensis provisionally in $\S$ NAGEIA, though the very characteristic branching of the peduncle (Fig. I4), the four vascular bundles of the ovuliferous scale (P1. LIII, Fig. 73), and the semicircular ridge which terminates it (P1. XLIX, Fig. I6, o.s.), together with the beak-like prolongation of the nucellus into the micropyle, are features which seem to distinguish it from all the other sections (Pl. L, Fig. 18, nuc.).

Morphology. This species, the Dakua Salu Salu of the Fijians, is the most beautiful forest tree of that country, or, in the writer's estimation, of the Conifers of the world. Moreover, the wood is the most valuable of the Fijian timbers, being not over hard and very durable. The magnificent symmetry of this species is striking. The splendid shaft, clothed in smooth white bark, rises sheer through the surrounding forest to expand in a crown of spreading branches, of which the ultimate shoots bear leaves so evenly arranged that they suggest pinnules on the frond of a huge fern. These leaves are light green in colour, coriaceous and shining in texture.

The strobili are borne on branching peduncles which arise on the axils of the lower leaves of the shoot in great profusion. The frond-like habit of the branches exposes the strobili, which are conspicuous from their bright magenta colour and glaucous bloom.

This colour, according to Cheeseman $\left(14\right.$, p. $\left.65^{\circ}\right)$, is also characteristic of $P$. ferruginea.

These strobili were collected from one tree, and show two stages, as already described for $P$. imbricata (see p. 525). The current year's cone shows the ovule in the unmodified nucellus or pre-pollination stage (Fig. I 5), which can be compared with the longitudinal section given for $P$. ferruginea, the structure being identical in both cases (Pl. LIII, Fig. 77). These cones were found at the apex of the axis on the youngest wood, on which the leaves had not yet expanded.

In a few cases ovules in the dividing macrospore stage were found on the same axis as the older cones, as figured for P. imbricata (Pl. XLIX, Fig. I, strob. I and 2). These older cones (Fig. I6) occur in the axils of the lower leaves of the secondary branches of the immediately older wood (Fig. I4, strob.). Whether this wood is last year's or not it would be impossible to decide from a single observation on a tropical tree of which no data for judging 
the rate of growth are available. In the older cones the ovules show the prothallus contracted in every case. These ovules are in the pre-fertilization stage, as archegonia can be traced in the contracted prothallial tissue, and the pollen-tubes have completely penetrated the apex of the nucellus.

In Podocarpus, in all sections except $\S$ DACRYCARPus, the 'epimatium' (lamina of the ovuliferous scale) is described $(40$, p. 18$)$ as being free from the short fleshy point of the 'carpel' (lamina of the fertile bract), which the ovule greatly exceeds.

The 'carpels' are described by Pilger (40, p. I3) as extremely rudimentary, and of the scale-like leaves which in their entirety represent the 'female flower' of the Podocarpoideae (meist zu einem Teil fertil als Carpiden entwickelt) generally only one is fertile and can function as a 'carpel'. In $\S$ NAGEIA in some species a 'receptaculum' (1.c., p. I5) is developed, in others not. When there is no development the stalk of the 'receptaculum' is not naked but bears rudiments of scale leaves, while the scales (Schuppen) of the 'receptaculum' are not decussate, being present in greater numbers in spiral sequence (1. c., p. 16).

In $P$. vitiensis the peduncle is covered with imbricating scale leaves as described in the two former species, which do not appear 'rudimentary' when examined in this early stage. The strobilus consists of six to ten bracts (Fig. 15, strob.) which show the same spreading laminae and elongated bases fused with the axis of the peduncle general in the order. The terminal, or sometimes the two terminal bracts (Fig. $16, f . b r$.) are fertile. These bracts are sub-opposite and the laminae show a protective function in the young stage (Fig. 15, o.s.), folding over the fertile bract and the ovuliferous scale, and opening out later (Fig. I6, s. br.). To describe these bracts as scales is hardly logical, as their organization is entirely similar to that of the foliage leaf; also the spiral sequence of the scars of the caducous bract laminae seen on the mature peduncle may be due to subsequent development during the elongation of the axis. In this species the laminae of the bracts persist till the fertilization stage (Fig. I6, f. br.). A bract can hardly be described as a rudimentary scale merely because the lamina is caducous, the scars alone being present at maturity. This fact would rather point to an advance in economical organization, a useless member being shed when no longer required.

In Fig. I5 the lamina of the fertile bract encloses the ovuliferous scale $(f . b r$. and o.s.) with ovule, reaching to the apex of the same. In longitudinal section of $P$. ferruginea in the same stage, the structure of which, with the exception of the broadened apex, is identical with that obtaining in $P$. vitiensis, the lamina of the fertile bract is seen to be perfectly free from that of the scale (Pl. LIII, Fig. 76). In Fig. 77 in transverse section the base of the bract is shown coalescing with the base of the scale, but, as in $\S$ DACRYCARPUS, there is no fusion of bundles; both vascular systems remain 
distinct till they are separately inserted on the strobilus system. It is therefore obvious that one cannot describe the fertile bract properly as a 'carpel', considering that there is no vascular connexion with the ovular tissues.

In the older or pre-fertilization stage the ovuliferous scale has grown well above the bract (Fig. 16, o. s. and f. br.).

The scale or 'epimatium' can, however, hardly be described as greatly exceeding the 'carpel', nor can. we speak of these 'carpels' as extremely rudimentary. They are, on the contrary, well-developed bracts, showing a transitory strobilus organization instead of a permanent one as in Saxegothaca. This organization is for the development and protection of the ovule till the ovuliferous scale can assume independent function.

The peculiar semicircular ridge formed by the apical portion of the ovuliferous scale is very prominent. Sometimes it projects in two or three points (Fig. I4, o. s.), but this effect is no doubt due to contraction of tissue. More than half the ovules sectioned were found to be full of tiny insect eggs, which replaced the integument.

Histology. In longitudinal section of the pre-fertilization stage the lamina of the fertile bract is now very inconspicuous in relation to the welldeveloped ovuliferous scale (P1. L, Fig. I7, lam.f.br.).

The ovuliferous scale shows the same foliar structure as in §DACRYCARPUS. There is a cuticularized epidermis and well-developed mesophyll with many tannin cells, but as yet no lignified tissue in the scale which reacts to phloroglucin.

In transverse section of the dividing megaspore stage, taken through the centre of the nucellus, eight bundles are shown in the adherent lamina of the ovuliferous scale (Pl. LIII, Fig. 72). The vascular system of the ovuliferous scale consists of four distinct bundles with inverted orientation and accompanied by four resin canals, which arise in the apex of the scale, and form a ring-like expansion at the base of the ovule, where each bundle divides again, and the eight branches run down the adherent lamina of the ovuliferous scale surrounding the ovule.

The epidermal tannin layer of the micropylar apex of the integument is well shown, also the tanniferous nutritive zone at the base. A similar layer limits the nucellus, and phloem strands show on each side penetrating both zones of tannin cells. Surrounding the megaspore is a tapetum of several layers of cells.

In Fig. 73 a transverse section of the same series, taken through the micropyle, shows the four main bundles, which have again approached each other, on the axial side of the scale towards the base of the latter. On the opposite side the apical portion of the integument is seen, still limited by the zone of tannin cells. In the lamina of the ovuliferous scale which surrounds the integument, the resin canals belonging to the ring of vascular bundles shown in Fig. 72 are still apparent, as they are continued beyond 
the strands. These resin canals must branch independently, as more canals appear in the lamina surrounding the ovule than there are vascular strands (Pl. LIII, Fig. 73).

In longitudinal section of the pre-fertilization stage the branches from the inverted vascular system surround the ovule in the lamina of the scale (Pl. L, Fig. I7, v. b.o.s.) and are seen running down to the micropyle. These strands end in the usual group of tracheides (Fig. I7, tra.). This branching of the vascular system to serve the lamina of the scale is also present in $P . \mathrm{im}$ bricata (P1. XLIX, Fig. 6, v.b.o.s.). Several strands of phloem elements, of narrow elongated cells with densely staining contents, pass from the phloem of the bundles across each zone of nutritive tannin cells to the base of the nucellus (Pl. L, Fig. I $7, p h . s t r$. ) as previously described in transverse section (Pl. LIII, Fig. 72), where they show on both sides penetrating the zone of tannin cells of the integument. The strand rising a little above the bract, which runs parallel to the vascular bundle for a short distance (Pl. L, Fig. I7), was present in every ovule sectioned. A phloem strand penetrating to the nucellus is also present in the ovules of Agathis, connecting them with the vascular supply, a fact which has been recorded by Worsdell.

The usual zone of starch and tannin cells limits the base of the integument, of which the apex shows elongated spirally thickened and pitted cells (Fig. I7, lig. c. int.).

The base of the mucellus is marked by another zone of tannin cells (Fig. I7, tan. and st.c.). The nucellus has a markedly long beak formed of serial rows of cells (Fig. I8, muc.) which are not thickened but merely crushed at the extreme apex (Fig. I 8, stig. $a p$.). This beak is penetrated by pollen-tubes which run more or less vertically down it. In one case the $o^{7}$ prothallus was seen in the archegonial cavity (Fig. I8, or pro.), containing two generative nuclei with stalk and tube nucleus. In this stage, according to Lawson in Sciadopitys verticillata (30), there is an interval before actual penetration into the archegonia.

The nucellus is limited on the interior by two or three tapetal layers with disorganized cells surrounding the gametophyte (Fig. I7, tap.). The t gametophyte has absorbed about two-thirds of the nucellus and (Fig. I7, pro.) shows a prolongation into the beak of the latter.

In all material obtained, though much contracted, a megaspore membrane is traceable (Fig. $\mathbf{I} 7, m . m$.).

\section{$\S$ STACHYCARPUS.}

Receptaculum nullum; flores feminei spiciformes vel ovula I-2 ad apicem ramulorum abbreviatorum.

$$
\text { P. spicata. }
$$

Morphology. P. spicata, the Matai or Black Pine of New Zealand, is a very graceful tree, with a round and densely branching crown, and 
leaves unusually delicate in texture and dark in colour, with silvery undersides. It is general in forests throughout the country, up to 2,000 ft., according to Cheeseman $(14$, p. $65 \mathrm{I})$, who describes the wood as hard and durable.

The flowering shoots, both $\sigma^{7}$ and $q$, are exceedingly numerous, but both in the Ohakune and Nelson material the ovules were mostly attacked by some insect grub, aborted and abnormally swollen.

Miyake, in Abies balsamea (33, p. I34), describes more than half the ovules examined as being infested by insect larvae; in early stages they were impossible to distinguish from those not infested. In the present instance $P$. vitiensis (1. c., p. 536) was found to be similarly infected. In a purely endemic species limited to a small country, where even in its native habitat it is only of local occurrence, such infection, spread over a series of years, would very soon work out its extinction. This is the case in California with Pinus radiata, now practically limited to the Monterey Peninsula, and to more or less isolated groups through the coast country, where it is subject to specialized insect attack. In accounting for the dominance or recession of species this very evident but passive factor, as far as the plant is concerned, is as a rule neglected, and most emphasis is laid on the possible active participation of the plants themselves in the struggle for existence, the survival of the fittest being attributed to superior organization and response to ontogenic requirements or to natural selection.

The flowering shoot consists of an elongated axis, borne in the axils of the foliage leaves of the young wood (Pl. L, Fig. I9, strob.). The shoots show the protective bud scales at the base ; these are succeeded by apparently opposite and decussate modified leaves, an arrangement subsequently lost with the elongation of the axis. The laminae of these modified leaves are suppressed, the bases being adpressed to the stem axis (Fig. 20, l.). That these are modified leaves is shown in Fig. 2I, where the laminae have grown out as ordinary foliage leaves. These leaves, as a rule reduced to their bases, are followed by the fertile bracts, exactly similar in structure, with the bases fused with the axis and laminae more or less suppressed. Above the bracts is an apical bud (Fig. 20, ap. bud) always pressed to one side by the development of the last fertile bract.

Pilger (40, pp. I3, I 4) describes the of flower in this species as a spike, consisting of a short limited branch, with a thin axis, bearing spirally arranged scale leaves at equal distance on it, which run down the axis, and at their base bear each an ovular rudiment. He describes the branch as bearing only 'carpels', but this 'Verhalten' is often modified so that the lowest leaves may be sterile. In the present instance the sterile leaves were invariably found to be present, as described above (Figs. I9, 20, 2I, l.). The fertile bracts are given by Pilger as about 8 , whereas Cheeseman $\left(14\right.$, p. $\left.65^{\circ}\right)$ gives them as $2-8$.

In the present investigation, one axis was found with one fertile bract 
(Fig. $2 \mathrm{I}, f . b r$.) and a great many with $3-5$ (Figs. 19 and $2 \mathrm{I}$ ). In every case the axis was terminated by a bud pushed on one side by the growth of the last fertile bract (Fig. 20, ap. bud). In no case, and a great deal of material was available, were the bud-scales and modified leaves of the axis and the apical bud absent.

In Fig. $2 \mathrm{I}$, where only one ovule was present, a cicatrized scar showed where the apical bud had been broken, or more probably eaten off. This fact had possibly caused the modified lower leaves to develop laminae and so grow out as ordinary foliage leaves.

In the or shoots, as stated by Pilger, the same conditions obtain. Ten to thirty flowers are massed on an axis about $5 \mathrm{~cm}$. long, where they may arise in the axils of small bracts only, or the shoot axis may bear foliage leaves at the base, which gradually pass into the bracts, the lowest flowers being borne in the axils of the foliage leaves, and an apical bud may develop (40, p. Io).

The $q$ 'spike' of $P$. spicata may be regarded as an entire strobilus, and fossil evidence may be referred to in support of this interpretation. Nathorst (62) describes in Stachyotaxus septentrionalis, C. A. Agardh, and Stachyotaxus elegans, Nath., an almost identical structure. He figures the strobilus of the former (62, Figs. I and 2, t. 2) and the resemblance is very striking; these figures show scale leaves densely clothing the peduncle, which are succeeded by a number of bracts, all of which are fertile, inserted at regular intervals on the axis. Nathorst refers to the similarity in structure of the $q$ shoot of this plant (which he rightly holds to be a Dacrydium) with $P$. spicata $(62$, p. I5). The $t$ strobili of Stachyotaxus show the elongation of the axis with the spacing of the sporophylls which is so striking in the $q$ strobilus in this genus. Nathorst figures these $t$ strobili with reserve, as they have not been found in organic connexion with Stachyotaxus, but they are so typically Dacrydioid that there can be little doubt that they belong to the same plant.

In $\S$ STACHYCARPUS the lamina of the fertile bract remains free from the ovuliferous scale, and does not keep pace with its growth, as described and figured in $P$. vitiensis (Fig. 27). The region of the ovuliferous scale referred to in the description of $P$. vitiensis as the semicircular ridge is in $\S$ STACHYCARPUS more prominently developed, and appears as a conical apex projecting from the free side of the ovuliferous scale above the place of insertion of the ovule. Pilger describes this pointed apex as a narrowing of the 'epimatium' into a blunt continuation ('stumpfen Fortsatz'), but as this continuation is furnished with two well-developed vascular strands with resin canals (Fig. 22, v. b.o.s.), and the foliar structure of the scale in the shape of epidermis, stomata, and stone cells is equally and continuously distributed, it seems to indicate that it is an integral portion of the scale itself. The greater development of this region may be related to the water 
supply of the ovule, in the absence of all swelling and proliferation of tissue in the bract bases or so-called ' receptaculum' of the axis. A double apex is often apparent in the ovuliferous scale (Fig. 20, o. s.), this appearance being caused by contraction of the mesophyll tissue between the two vascular bundles, as previously noted for $P$. vitiensis (see p. 536).

Histology. In longitudinal section the ovuliferous scale is marked by a well-developed epidermis with stomata. Pilger $(40$, p. 23$)$ notes that in $\S$ STACHYCARPUS a thick stone-cell area arises evidently from the integument, but it will be seen that this area arises in the ovuliferous scale (Fig. 22, o.s. stone c.), the cells occurring in groups of two or three (Fig. 22) at regular intervals in the mesophyll. In this species stone cells were not found in the foliage leaves. The vascular system tissue consists of bundles which arise in the above-described apex of the scale. They lie facing each other, or phloem to phloem, separated at the apex by a little mesophyll. The separation increases as they descend till they expand at the base of the ovule in a ring of branching strands. Each bundle then divides so that four strands, all showing inverted orientation, and accompanied by small resin canals, surround the ovule in the lamina of the ovuliferous scale. On the dorsal side, or midrib region, below the ovular insertion, the two bundles approach each other again, but laterally, that is to say, side to side, until in the micropylar region the xylems almost converge, the phloem gradually rotating outwards.

Phloem strands penetrate to the nucellus (Fig. 22, ph.str.) as described in $P$. imbricata and $P$. vitiensis.

The integument is outlined by tannin and starch cells round its whole periphery (Pl. LIII, Fig. 75), and at the apex, at the micropyle, shows ingrowth of lignified closing cells (Pl. L, Fig. 22 a, lig.c. int.), as Saxton has described for Widdringtonia (42, p. 32 ), the cells similarly showing no septation and not entirely closing the opening.

The apex of the mucellus is prolonged, the cells containing starch, and the cell-walls show slight collenchymatous thickening (Pl. LIII, Fig. 74). It is this difference in texture and contents which is the cause of the slight contraction apparent at the base of the apex (Pl. LIII, Fig. 75), which is sometimes so marked in species where the apex is long, that the nucellus appears bottle-shaped, and this cause must always be allowed for in the presence of . apparently abnormal shape. Pollen-tubes are seen penetrating the stigmatic apex (Fig. 75). These tubes extend above the actual apex, still attached to the spore-case; the loose cells forming the stigmatic surface of the extreme apex on pollination gradually become contracted and pressed together, the upper portion of the tube being in consequence exposed.

The base is outlined by the nutritive zone (Fig. 74). The tapetum is well marked in the region of the growing gametophyte (Figs. 74 and 75 ), which in Fig. 75 has absorbed nearly the whole of the body of the nucellus.

In Fig. 75 the $q$ gametophyte is almost filled by the centripetal growth of the endosperm, in which cell-wall formation is beginning, but so much 
contraction has taken place that the tissue is folded in and out, the outlines being traced by the megaspore membrane, which follows the folds (Fig. 75).

Of the two microphotographs of longitudinal sections given, Fig. 75 is older than Fig. 74, which shows the same stage as Pl. L, Fig. 22.

\section{P. fermiginea.}

Morphology. $P$. ferruginea, or Miro, is a very handsome New $Z$ ealand tree, which with $P$. dacrydioides forms an exception amongst the Podocarps of that country in not suggesting the Yew in foliage and asymmetrical habit.

The branches of this tree are not crowded and recall $P$. vitiensis in their rather horizontal spreading, and light green and shining leaves, with distichous arrangement. The fruit is also the same colour.

Cheeseman (14, p. 650) gives it as abundant throughout the country, the wood hard and compact, but not durable in exposed situations.

The strobili are borne on the apex of small lateral peduncles which arise in the axils of the lower foliage leaves of this year's wood (Fig. 24, ped. strob.), and as in $P$. imbricata, last year's ovules, in the pre-fertilization stage, and this year's with a homogeneous nucellus and dividing macrospore stage, were obtained on the same tree.

The lower portion of the peduncle of the strobilus is densely covered with imbricating scale leaves in the youngest stages, as in $P$. vitiensis (Fig. 27, s.l.). These scale leaves gradually pass into the bracts of the strobilus. The strobilus terminates the apex of the peduncle and is composed, as far as could be determined, of six to eight bracts of fleshy consistency, arranged in a decussate manner, with the bases fused with the axis, and with expanded laminae. One of the terminal pairs of bracts (Fig. 27, f.br.) or both (Fig. 28) are fertile.

The laminae of these bracts do not persist as long as in $P$. vitiensis, but soon fall off, including even the lamina of the fertile bract, leaving only cicatrized scars (Fig. 29, scar lam.f.br.), but the scale leaves of the peduncle persist.

Pilger (40, p. I4) emphasizes the spiral sequence of the bracts or 'carpels' in $\S$ STACHYCARPUS in comparison to their opposite and decussate position throughout the Eupodocarps, but the tendency is really the same in both cases, viz. an opposite and decussate arrangement due to economy in packing, in the youngest stages, which is gradually lost sight of on the elongation of the axis when the spiral phyllotaxy of the leaves come into play as the permanent arrangement.

These bracts surround and protect the fertile ones in the young state (Fig. ${ }_{25}, b r$.), expanding and reflexing later (Fig. 27, s. brs.). The lamina of the fertile bract at first covers the ovuliferous scale almost as if it were fused with it, as in $\S$ DACRYCARPUS. However, in longitudinal section it is 
seen to be free from the latter (P1. LIII, Fig. 76). Where two bracts are fertile, they appear to be opposite, but, as stated before, this is only a question of packing, as one is invariably younger than the other (Pl. L, Fig. 28, o.s. $)^{1}{ }^{1}$

Histology. In a microphotograph of a radial longitudinal section of the youngest stage available (P1. LIII, Fig. 76) the initial distribution of the tannin cells shows well. They are seen in three or four layers outlining the bases both of the fertile bract and scale, also the laminae of both, to continue in the epidermis only of the latter in the region of the micropyle, and in that of the integument and nucellus, where free (Fig. 76). This distribution is further emphasized in transverse section of the same stage, taken through the nucellus (Fig. 77)

There are, as yet, no tannin cells at the periphery and base of the integument and nucellus. This zone is initiated, as in Saxegothaea (57, p. I44), with the enlarging megaspore on pollination. In Fig. 76 the cells at the base of the ovule are in active division, the zone of growth being basal, as Saxton (44) describes for Callitris. The apical cells of the integument at the micropyle are not yet lignified.

The base of the ovuliferous scale on the ventral side shows swellings, which recall the structure of the scale bases in $\S$ DACRYCARPUS (P1. XLIX, Figs. 8, 9, and I 3 ).

Two bundles, with resin canals, showing the usual reversed orientation, run down the scale (Pl. LIII, Fig. 77). The course of the bundles is essentially as described for P. spicata (see p. 540). These bundles arise in the apex of the scale, which is produced (P1. L, Fig. 29, 0.s.), though not to the same extent as in P. spicata.

The two strands, each with a resin canal, do not exactly face each other in the extreme apex, as in the above species, but converge more or less as they descend the scale (Pl. LIII, Fig. 77), gradually rotating until the phloems are side by side. Then the strand of the fertile bract slips in between and the three bundles are inserted on the ring of distinct bundles in the strobilus.

In the fertilization stage from the same tree (P1. L, Fig. 29, o. s. scar brs.) the ovuliferous scale rises well up above the bracts. The imbricating scale leaves of the peduncle still persist, but the laminae of the bracts of the strobilus have been shed, including that of the fertile bract, leaving only cicatrized scars.

1 In $P$. ferruginea we get an interesting reduction in the organization of the strobilus as compared with that of $P$. spicata. The peduncle, clothed with scale leaves, is shortened, as is also the axis of the strobilus, on which the bracts are massed close together, and not only reduced in number but also in fertility, the lower ones being all sterile, with one or two of the apical bracts alone fertile, and there is no apical bud. This reduction is also indicated in the Stachyotaxus series, as in S. elegans (62, t. 3, Figs. I and 2). Nathorst figures the strobili in a similar lateral position, with the peduncle reduced in length and in the number of bracts, all of which are fertile, but, though still showing an appreciable interval between each bract, the spacing is more than is the case in S. septentrionalis. 
In the ovuliferous scale groups of stone cells are arranged regularly in the mesophyll as in P. spicata, but, unlike that species, they also occur in the mesophyll of the foliage leaves. The vascular strands start from hypodermal groups of tracheides (Fig. 34) at the apex of the scale and spread ring-like round the base of the ovule, where a phloem strand penetrates to the base of the nucellus, as in $P$. imbricata, vitiensis, and spicata. The bundles show no secondary branching in the lamina of the scale (Fig. 29, v. b. o.s.).

The integument shows the greatest differentiation yet met with, as the peripheral zone of tannin cells tends to elongate laterally, broadening out towards the centre and tapering towards the micropyle (Fig. 29, tan.c.). This regular arrangement is peculiar to this species amongst all those included in the present investigation.

Of the mucellus all but the apex, of which the cells show thickening of the cell-walls and starch contents, is absorbed by the $q$ gametophyte. The apex is penetrated by numerous pollen-tubes, the spore-cases being still attached to the stigmatic surface. The pollen-tubes penetrate more or less vertically, crushing the tissue on either side as the contents become absorbed. In all species this crushing of the thick cell-walls gives a certain stability to the apex, which persists till the embryo stage, forming a little brown cap which can be removed from the apex of the $q$ prothallus when the latter is dissected out.

The $q$ gametophyte is very contracted in the material available, but cell-wall formation can be traced.

It is limited by a megaspore membrane of two layers, the outer one striate.

\section{$\S$ EUPODOCARPUS.}

Flores feminei singuli axillares, sub-sessiles vel plerumque longius pedunculati; receptaculum evolutum, saepe basi foliolis 2 angustis instructum.

In $\S$ EUPODOCARPUS the strobilus occurs, as usual, in the axils of the lower foliage leaves of lateral shoots. In these shoots there is always a well-marked fertile area of about an inch to an inch and a half. Above and below this area no strobili are to be found. It is only noticeable in the young wood up to pollination stage, as after that the unfertilized strobili drop off in great numbers, and it is no longer apparent that every leaf in this limited region bears a cone in its axil.

The strobilus may be almost sessile or pedunculate. If pedunculate the peduncle is naked, the strobilus consisting of two to six bracts, the two lower ones in some species (which Pilger in his monograph places first, and whose presence he considers divides § EUPODOCARPUS into two large groups, geographically separated (40, p. I4)) being thin, strap-like, and generally unmodified. The upper bracts show the small laminae and relatively large bases, which swell up as growth proceeds, and fuse with 
the axis and with each other, as previously described in $\S$ DACRYCARPUS. But in $\S$ EUPODOCARPUS the swelling is carried much further, resulting in a berry-like structure, in which the laminae are not traceable, or merely indicated by points.

This berry-like structure of swollen tissue forms the so-called ' receptaculum' which A. Braun $(8$, p. 740$)$ was the first to reduce to its proper status.

That the two strap-like 'folioles' of Pilger really belong to the strobilus is seen in $P$. spimulosa, R.Br., where Pilger $(40$, p. 77 , Fig. I 5, $\mathrm{H}-\mathrm{L}$ ) shows that their bases may become swollen and so resemble the other bracts of the strobilus.

In their strap form these bracts are very caducous and so approach those which compose the strobilus in $P$. vitiensis and $P$. ferruginea.

Flores feminei infra receptaculum foliolis 2 parvis linearibus ornati.

$$
P \text {. elata. }
$$

Morphology. $P$. elata was found as a slender tree with sparingly branched crown in the montane mixed forests of Fiji, growing about $30-5 \circ \mathrm{ft}$. high; on higher ridges, of shrubby habit, about $20 \mathrm{ft}$. and fruiting at 9-1o ft. The leaves are Willow-shaped, about 3 inches long, crowded towards the ends of the branches. The recorded distribution is for Queensland, New South Wales, and New Caledonia.

In this case also two stages were found on the same tree, as previously recorded for other species. The strobili arise in the axils of the lower leaves of the secondary branches of the young wood, and in September were in the pre-pollination or homogeneous nucellus, to the formation of the functioning megaspore stages (Figs. 30 and 32 ).

On the next oldest wood, the ovules were much larger, showing young embryos, with the cotyledons just forming, the bracts of the strobilus being already swollen and fused (Fig. 33).

This species shows the unmodified lower bracts (Fig. 33, l.brs.), which in the youngest stage are not so differentiated from the upper ones, and form an integral portion of the strobilus (Fig. 30, l. brs.), enclosing and protecting the upper bracts. They are evidently the reduced remains of the more highly organized bracts that obtain in $P$. vitiensis and $P$. ferruginea, whose function is also protective (Figs. I 5, 25, and 27). No geminate cones were seen in this species.

In Fig. 30 the sterile bract has been removed to show the ovuliferous scale, with the lamina of the fertile bract well above it (o. s. and $f: b r$.).

On the dorsal side of the same strobilus (Fig. $30 a$ ) the fertile bract is seen to be unmodified in structure.

The ovule at this stage would show a homogeneous nucellus (Pl. LIII, Fig. 79). In Pl. L, Fig. 3 I, in an older stage, the bracts and the ovuliferous scale are about the same level, and the ovule would be showing sporogenous 
tissue. In Fig. 3I $a$ the lower bracts have been dissected off, exposing two bracts, one fertile, of which the laminae begin to show marked contraction and the bases are swelling up. In Fig. $3 \mathbf{I} b$ the micropyle of the ovule can be seen. In Fig. $3^{2}$ the ovule is well above the bracts; there is more swelling in both the latter, with greater contraction of the laminae (Fig. 33, $l a m$. and $b r . b s$.$) . This would be approximately the dividing macrospore$ stage.

In Fig. 33 the embryo shows cotyledons differentiating. The unmodified lower bracts have expanded, and in most cases were already shed. The bract laminae are reduced to points, while the bases have swollen enormously. The structure of these bases is essentially the same as described in $\S$ DACRYCARPUS. The tissue shows the same uniform cells with colourless contents, freely interspersed with tannin cells, especially (P1. LIII, Fig. 79) round the periphery. The increase in size is due to the proliferation of the mesophyll tissue cells, which with very thin walls and no cell contents suggest a water-storage function ; the fact, too, of the very early development of this tissue points to some provision for the wants of the growing ovule, which in its isolated position is rather remote from the supplies of the sporophyte. The increase in this tissue, which characterizes the Eupodocarps, may be possibly correlated with the absence of scale leaves on the peduncle.

In $\S$ DACRYCARPUS, where the scale leaves are present, this tissue is reduced (P1. XLIX, Figs. 4 and I2). In $\S$ STACHYCARPUS, where, though fused for their whole length to the peduncle, the bract bases do not swell up (P1. L, Fig. 28), the provision in the younger stages is much better, as the bracts then are more numerous and more specialized, each is of fleshy consistency, larger scale leaves support the base of the strobilus, and these merge into the smaller and more densely imbricating scale leaves which clothe the peduncle.

Histology. It is interesting to compare a photomicrograph of the homogeneous nucellus, which would be represented in Fig. 3 I and Pl. LIII, Fig. 79 of $P$.elata, with Fig. 76 of a slightly younger stage of $P$. ferruginea, in $\S$ STACHYCARPUS, as the different development of the bract bases, also variation in form of the ovuliferous scale in each section, can then be better appreciated.

Fig. 79 is a radial section and shows well the foliar structure of the scale, from which, as far as seen in Eupodocarpus, hypodermal fibres are absent, both from the ovuliferous scales and the foliage leaves. The beginning of the nutritive starch and tannin zones is present at the base of the integument and nucellus. This section also shows how distinct the organization of the ovuliferous scale is from that of the fertile bract, the former having no vascular connexion with the lamina or so-called 'carpel'.

In Fig. 79 the base of the ovuliferous scale is distinct and forms an integral portion of the strobilus, being pressed between the bract bases and fused with them. In the series of sections of the strobilus the three 
vascular strands can be traced separately to the base of the same. This distinctiveness is shown in the section figured, by the separation of the two resin canals, viz. that of the sterile bract to the right and that of the ovuliferous scale in the centre. Only a trace of the vascular bundle of the fertile bract is visible (Fig. 79) to the left, but that is sufficient to show how widely it is separated from that of the ovuliferous scale with its inverted orientation.

In transverse section of the same stage, a microphotograph (Pl. LIII, Fig. 80) shows a section taken through the base of the nucellus where the two bundles spread round the base of the ovule. It is slightly oblique, but the foliar structure of the scale comes out well. The lamina of the fertile bract appears on the dorsal side to the left (Fig. 80).

A prothallus, showing an embryo, was sectioned. The structure was identical with that described for $P$. imbricata (see p. 530).

\section{P. polystachya.}

Morphology. This material was collected from a large tree growing in the Buitenzorg Botanic Gardens. The leaves are long and Willow-like, aggregated towards the end of the branches. The strobili arise in the axils of the foliage leaves and consist of apparently two bracts, of which one is fertile. The unmodified lower bracts are no longer present $(\mathrm{Pl} . \mathrm{L}$, Fig. 35). The ovules all show different stages of pro- and embryo formation (Figs. $3^{6}$ and 37 , and P1. LI, Figs. $3^{8}$ and 39 ).

Histology. Some of the ovules were much smaller, suggesting earlier stages (Pl. LI, Fig. 4I), but, on sectioning, these showed sterile prothallia, in which pollen-tubes, however, had penetrated the whole length of the persistent apex of the nucellus in each case (P1. LI, Fig. $42, p$. t.).

In both fertile and sterile prothallia there is a well-marked epidermis, showing small uninucleate cells which contain little or no starch (P1. LI, Fig. $39 b$, epi.) with thickening of the outside cell-walls. Coker has also described and figured a similar layer for $P$. coriacea $(15, \mathrm{p} .97)$. This epidermis in the sterile prothallia was folded in and out over the apex and even into the neck of the archegonial cavity, owing to contraction of prothallial tissue.

Below these convolutions is a cavity (P1. LI, Fig. 42, dis. arch.) where the archegonia would normally occur, but of which no trace was to be seen. In the central cylinder of small cells which reached below the cavity to nearly the base of the prothallus were a great many tracheides (Fig. 42, tra., and Fig. 43). Neither the central cylinder nor the rest of the prothallus contained starch in the cells, though most of them were binucleate. This absence of storage contents was strikingly shown in a similar prothallus cleared in cedar-wood oil. The transparency was so great that the cylinder of small cells showed clearly through the centre, giving a very slight opaque effect, otherwise the prothallus would have been invisible. On cutting, 
it proved quite sterile, showing the apical cavity and just one or two tracheides in the central cylinder.

Coker $(15$, p. 97) gives a similar instance in $P$. coriacea. In that case there were two prothallia in one ovule; neither had formed archegonia, and in one three to four tracheides occurred in the central cylinder.

In the fertile prothallia the earliest stage is shown in Pl. L, Fig. 36, where many proembryos form a complex which has excavated a cavity in the prothallial tissue below the archegonia, from each of which a proembryo seems to be formed. This is also the case in $P$. coriacea $(15, \mathrm{p}$. IOI). These embryos were, with the suspensor tubes, rather contracted, but as far as could be made out resembled essentially those figured by Coker for that species.

One suspensor had penetrated vertically into the prothallus (Fig. $3^{6}$, sus.), showing a tiny embryo of about twenty cells at the basal end (Fig. 36, emb.). Immediately below it, in the central cylinder, the cells were densely packed with starch (Fig. 36, cen. cyl.). All the cells of the cylinder were multinucleate, mostly containing four nuclei (Pl. LI, Fig. 40). This division must be very simultaneous, as the daughter nuclei are still enclosed in the limiting membrane. Miss L. Digby, in looking over the sections, came to the conclusion that the divisions are mitotic. This agrees with Coker's (15) and Miyake's (34, p. I0) conclusions. The large peripheral prothallial cells showed very little starch, but dividing nuclei.

In Pl. L, Fig. 37 the disorganized remains of the embryos and suspensors still persist (dis. emb. and sus.), but the cavity they lie in has shrunk, while the embryo has increased in size, the suspensor tubes being still traceable. Contraction of tissue is shown at the apex (Fig. 37) and similar contractions occur round the periphery of the prothallus, whose tissues are filled with starch.

In Pl. LI, Fig. 38 a section of the ovule with the ovuliferous scale is given. Stone cells are thickly scattered through the mesophyll, with no group arrangement. The vascular bundles show laminal branching (v.b.o.s.).

The integument has very much shrunk, centripetal lignification having begun in the cell-walls, while nothing remains of the nucellus but the cap (Fig. 38 , nuc. cap), still showing starch and traceable pollen-tubes.

The megaspore membrane, though present, is very difficult to see, and cannot be dissected off, but in sections a thin line of cuticle persists in iodine and sulphuric acid.

The cavity of the proembryo complex has quite closed up and the embryo is seen in the centre of the prothallus, with digested cell layers on each side, and a plug of the crushed and empty cells of the central cylinder at the base (Fig. $3^{8}$, cen. cyl.). This embryo shows no differentiation.

In Fig. 39 the cotyledons are differentiated, also the root apex. The embryo shows resin canals surrounding the phloem, which are present even in the cotyledons. Pressed between the cotyledons and spreading 
below them is the plug of the crushed axial tissue. The prothallial cells are packed with starch (Fig. 39, st.) which thins off towards the periphery, and where embryo digestion is in progress.

As many as eight nuclei may occur in the cells, which show up clearly in iron-alum and haematoxylin, counterstained with Congo-red (Fig. 39 a, muc.)

In the Podocarps, in the endosperm tissue, all the nuclei seem to remain active, and their division suggests a correlation with the demands of starch formation, as this division is initiated at the beginning of the latter after fertilization and keeps pace with its demands.

\section{P. bracteata.}

P. bracteatc, like the last species, was only seen in the Botanic Gardens of Buitenzorg. There it was a large tree, with very long narrow leaves. The leaves in this species are verticillately arranged and very large, about four inches long and three-quarters of an inch broad, markedly dark green in colour. Pilger $(40$, p. 80$)$ has sunk $P$. bracteata, Bl., in P. neriifolia, Don, but as the plant was labelled by the former name, that designation is naturally adhered to. Only mature cones were collected.

The strobili occur singly in the axils of the foliage leaves on very short peduncles, the bract bases being much swollen, full size, and of a dull purple colour, with all trace of individual parts entirely lost (Fig. 44, $b r . b s$.$) . The mature seed-coat is thick and resisting; lignification takes$ place in the cells of the integument, and involves the adjacent tissues of the ovuliferous scale as well.

Histology. The youngest prothallus in longitudinal section shows the hypocotyl with root-cap of the embryo nearly reaching to the apex (Fig. 45, $h y p$. and $r t . c a p$ ), where it is capped by the crushed remains of the proembryos and suspensors (Fig. 45, crushed sus.). Empty tissue surrounds the embryo, with a plug of the crushed cells of the central cylinder at the base (Fig. 45, $c e n . c y l$.). In the embryo the outside walls of the epidermis are thickened, and two small roundish cotyledons show at the base, succeeded by the hypocotyl, in which the plerome cylinder is outlined by resin canals (Fig. 45, r.c.), and these occur also in the cotyledons, cortex, and root-cap. The root apex is well differentiated (Fig. 45, rt. cap).

In the fully developed embryo (Fig. $46, \mathrm{emb}$.) the root-cap projects out beyond the prothallus (Fig. $46, r t$. cap), breaking through the opening left by the archegonial cavity, and pressing aside the remains of the crushed suspensor tubes (Fig. 46, crushed sus.).

The limiting layers of the prothallus show crushing all round the embryo, while the basal plug is still in evidence (Fig. 46, cen.cyl.). The rest of the prothallial tissue has undergone little diminution in area and is packed with starch (Fig. 46, st.). This fact suggests that the embryo, in the oldest stage available material shows, has not yet reached its full development on the parent plant, though it is unusually well organized, in 
comparison with some Angiosperms, at this stage. Lloyd (32) has described vivipary in $P$. Makoyi, Bl., a species referred by Pilger $(40$, p. 79$)$ to $P$. macrophylla, Don, var. maki, Sieb. Naaml, from Japan, grown in the United States. He describes the hypocotyls as always extruding from the ovules, while the latter are still attached to the sporophyte. No histological details are given, so that it is impossible to compare the development of the embryo in each case.

In Fig. 46 all the growth in the embryo in comparison with the previous stage (Fig. 45, emb.) seems limited to the hypocotyl, the cotyledons remaining almost stationary in their development.

The structure of the hypocotyl is essentially that of a root. There is a limiting epidermis with small nuclei and no starch contents; this is succeeded by the cortical layers packed with starch and penetrated by resin canals, which are chiefly aggregated towards the periphery, and surrounding the plerome cylinder. The plerome consists of elongated elements with small nuclei and no cell contents. Two procambial strands, of two or three spiral vessels, occur, one on each side of the plerome cylinder (Fig. 46, procam. st.), alternating with the two areas of primary bast. The central pith consists of long, narrow, rectangular cells with no contents and several resin canals. Two strands pass into each cotyledon, which arise from the respective poles of protoxylem in the hypocotyl. Resin canals are distributed as in the latter.

Fig. 47 shows an embryo dissected out.

\section{$P$. neriifolia.}

This species in Fiji is of Willow-like habit, and regularly outlines the streams in that country, the branches spreading over the face of the water. The strobili are conspicuous, as the bracts and ovuliferous scale are unusually long in structure, and so stand well above the dark leaves, to which their glaucous bloom forms a pleasing contrast.

It was determined as $P$. bracteata, Bl., by Seeman (48, p. 266), who first collected it in Fiji ; but it does not appear to be the $P$. bracteata, Bl., as grown at Buitenzorg and put in $P$.neriifolia, Don, by Pilger $(40$, p. 80$)$, nor is the Fijian plant quoted in his monograph. The structure of the leaves is quite distinct. In the latter there are two lateral resin canals, in close association with the transfusion tissue, which forms a small group on the outer side of each resin canal; whereas in the former the resin canals are medianly placed, and quite distinct from the two lateral groups of transfusion tissue.

The leaves are not quite as long as in the Javan plant, and are much narrower. The Fijian habitat also, always on the banks of streams, has not been recorded for $P$. neriifolia in any other locality. 
The distribution of the latter is from East India, through Indo-China, Malaya, to New Guinea and Fiji. But the species in question from the latter country would be endemic.

The strobili occur in the axils of the upper leaves of the shoots, the peduncle varying in length from $3-5 \mathrm{~mm}$. The bracts are from five to six in number, the lowest pair unmodified and caducous, the upper with the bract bases being exceptionally long and attenuated (Figs. 48 and 49, br.bs.) ; the free laminae, as usual in the order, drying up in maturer stages (Figs. 50 and $5 \mathrm{I}$, lam. brs.). The upper bracts may be either equal (Figs. 48, 50, and 51 ) or sub-equal in size (Fig. 49); the arrangement also varies from subopposite (Figs. $48-50$ ) to sub-spiral (Figs. 49 and 51).

One (Figs. 48, 49, and $5 \mathrm{I}$ ) or two (Fig. 50) bracts may be fertile, but in the latter case, though opposite, one ovule is always younger than the other (Fig. 50), which shows, as before noted, that the opposite and decussate arrangement is merely apparent, and due to economy of space in the arrangement of the aerial portions of the members of the shoot, an arrangement always liable to modification, but that is not the inherent basis of construction.

Histology. In a microphotograph of a radial longitudinal section of this species (Pl. LIII, Fig. 78 ) in about the same stage as Pl. LI, Fig. 49 (dividing megaspore), the ovuliferous scale forms with the integument an unusually long micropyle. It is also very elongated in the basal region (Pl. LIII, Fig. 78).

The vascular system is of the usual type, consisting of two inverted bundles as previously described. Secondary branches run half-way down the lamina of the scale (Fig. 78), an unusual development at so young a stage. The secondary branches terminate each in a group of tracheides in the region of the micropyle. Each bundle is accompanied by a resin canal with functioning epithelium.

The integument shows the zone of starch and tannin cells with epidermal layer of the same. The hypodermal cells of the tip of the integument have the usual lignified and spiral thickening.

The mucellus is limited at the base by the zone of nutrient cells (Fig. 78). A tapetum of several layers surrounds the female gametophyte, which is in the dividing megaspore stage (Fig. 78). Older stages show many cells of the mesophyll tissue of the scale developing as stone cells. The micropyle is attenuated, the integument keeping pace in length with the long lamina of the scale, which possibly homologizes with the length of the foliage leaves in this species. The apex of the nucellus is not produced as a beak, but rather forms a depression. The nutritive zone of basal cells is very large round the nucellus, which is limited on the interior by a well-marked tapetum surrounding a contracted $\&$ gametophyte in the fertilization stage. 


\section{Flores feminei foliolis infra receptaculum destituti.}

$$
\text { P. saligna, D. Don. }
$$

$P$. saligna is well grown in several gardens in Cornwall, as $P$. chilina, L. C. Rich. The present material was obtained at Trewidden, Mr. Bolitho's place near Penzance, in March, 1909. The trees were still in their youth form of shrubby growth, fruiting at ten feet. There were very few cones, and they occurred in the axils of the lower leaves of last year's wood, and consisted of very long peduncles and three (Pl. LI, Fig. 52, br.bs.) or four (Fig. $53, b r . b s$.) bracts, of which one was fertile. The bract bases were green and somewhat swollen.

In Fig. 53 two bracts are of unequal size and all show a spiral tendency. This spiral tendency is carried still further in $P$. spinulosa, R. Br., judging from Pilger's figures (40, Fig. I 5, H-L). In this stage stone-cell formation has invaded the whole integument, which made it impossible to get good microtome series; the female gametophyte, too, was contracted and shrunken. It seems to be the rule that, where there is a difference in the relative size of the bracts of one cone, the fertile one is generally the largest; this enlargement is probably a subsequent development correlated with nutritive requirements.

\section{P. Totara.}

Morphology. P. Totara is one of the finest denizens of the New Zealand forest, and may be said to be the classical tree of that country. Its dark green foliage, rather pendulous in outline, massed branching habit, and stringy bark strongly recall the $\mathrm{Yew}$, a resemblance accentuated by the similar colour of the berry-like strobili. According to Cheeseman (14, p. 648), the wood is durable and much used for building purposes, and it was the favourite timber of the Maoris in the construction of their houses and war canoes. It is common in forests from the North Cape to the south-west of Otago, up to $2,000 \mathrm{ft}$.

The youngest material was collected during a two weeks' stay at Te Aroha, in the beginning of November, from a young $q$ tree in the public gardens. The stage of development ranges from the pollination or differentiated megaspore to free cell formation in the prothallus.

A great many of the ovules remained unpollinated, though there were several $\sigma^{7}$ trees in their immediate vicinity. These strobili died off by degrees in great quantities, and, though undistinguishable in the living state, they could always be picked out in formalin by their dead appearance.

As far as it is possible to judge by present experience, it seems to be characteristic of the Podocarps, no doubt associated with the reduced 
strobili, that the ovules are in much the same stage on the whole tree at one time. Even when last and this year's strobili are found there is little gradation in the stage of either.

Though constantly looked for, gradation in sizes was rarely obtainable on the same tree or even on others in the same locality.

Professor Macfarlane, on a recent visit to this country, mentioned the case of an isolated $q$ tree of Ginkgo, growing near Philadelphia, on which very few fruits matured each year. One year he tried the experiment of tying a bunch of $o^{7}$ flowers to the branches, with the result that the tree set a large crop of seed. The next year the experiment did not come off; he therefore decided to adhere to the exact date of the first successful result, which was again repeated, and that special date to the day has invariably proved reliable. The male trees were found to never vary in the maturation of the pollen, and by observing that date in the transportation of the $\sigma^{7}$ flowers the crop of seeds on the isolated $q$ tree could be controlled.

The experience at $\mathrm{Te}$ Aroha suggests a similar condition. Several $\sigma^{7}$ trees were quite near and covered with strobili; the one $f$ tree also bore an abundance of young cones in a lower fertile zone of the young shoots in such profusion as to be noticeable, notwithstanding their small size, on account of the glaucous bloom covering the entire strobili. Yet it was surprising how many were not fertilized. The cones would grow vegetatively for a little time and then drop off.

Possibly only those ovules in a physiologically receptive state when the pollen is shed can retain it. Stopes and Fuji (51, p. Io), in Ginkgo, note great uniformity in the development of the different ovules of the same tree, or even on different trees, and it has been remarked in the course of this work how uniform the stages are for the different species.

The strobili of $P$. Totara consist of three (Fig. 54, brs.) to four (Fig. 55 , brs.) bracts, which in the pre-pollination stage are quite unmodified (Figs. 54 and 55, brs.). Two are usually fertile (Figs. 55, 58, and 59), but, as we have seen before, one ovule is always younger than the other, showing that the apparently opposite and decussate arrangement of the bracts is merely an ontogenic convenience, not related to the actual organization of the plant, and probably induced by the shortness of the axis of the strobilus, to be lost on the elongation of the same, or an increase in the number of the bracts.

When three bracts are present (Figs. 54 and 56) the arrangement is evidently spiral. Pilger does not take into consideration this contingency, where the opposite and decussate theory cannot hold good. For P. Totara $(40$, p. 84$)$ he gives the 'receptaculum' as formed of two or four 'scales'; whereas, in the youngest stages, two bracts were not seen on the present occasion, always three (Figs. 54 and $5^{6}$ ) or four (Fig. 55), but the third one 
is completely lost sight of in the subsequent swelling of the bract bases. In section, however, the vascular strand is always traceable (Fig. $5^{8}$, v. $b ., 3 b r$.).

As growth increases the bract bases begin to swell a little, but the lamina are still distinct (Figs. $5^{6}$ and 58 ); by the pre-fertilization stage, however, their identity may be said to be entirely lost (Fig. 59).

Histology. In longitudinal section of the pollination stage the ovuliferous scale has grown well above the bracts (Fig. 57 , o.s.), and it shows a production of the apex above the insertion of the ovule. The vascular system of two bundles starts in this apex, each from a hypodermal group of tracheides. It spreads ring-like below the insertion of the ovule, but as far as the available material goes no laminal branching occurs (Figs. 57 and 58, v. b. o. s.). Resin canals with epithelium accompany the vascular supply on the ventral side, limiting the tissue of the integument, in which the nutritive cells are arranged in the normal zone (Fig. 59, tan. and st.c.).

The hypodermal cells at the micropyle show spiral thickening and elongation (Fig. 57, a.). The mucellus is roundly pointed, but not beaked; pollen-grains rest on the apex, but no tubes are traceable. Two or three layers of tapetal tissue limit the nucellus in the vicinity on the dividing macrospore (Fig. 57, tap.).

In an older stage (Fig. $5^{8}$, pro.) the $q$ prothallus shows free nuclei. In this case the tracheides of the vascular system of the third bract come into the section, though the presence of the former is not otherwise indicated (Fig. $5^{8}, v . b ., 3$ brs.).

In older stages again, collected at Auckland in October, the bract bases were already swollen up to their mature size and identical in colour with that of the Yew aril, points alone indicating the laminae (Fig. $59, b r . b s$.).

The cells of the bract bases show an increase in size and number, but not in contents, being evidently filled with a watery cell-sap. They retain their foliar structure; the proliferation of cells taking place in the mesophyll, the arrangement of the cell layers in this tissue is retained (Pl. LIII, Fig. 79).

The ovuliferous scale shows increase in length, and centripetal lignification of the cells of the integument, involving half its tissue, is in progress. A two-layered megaspore membrane surrounds the $q$ prothallus, which is very much contracted. Archegonia can be traced in the apex of the prothallus. Many of the cells show two nuclei, which would point to the maturation of the oosphere (see p. 530). This would agree with the development of the ovular tissues, and the contraction of the prothallus shows that endosperm formation has not yet been initiated.

In this case we see that the swelling and coloration of the bract bases, which are turgid with a sweet cell-sap, are present long before maturity. This development can therefore be of no use to the plant in facilitating distribution by the agency of birds, as stated by Pilger (40, p. 22). 
It may possibly have this secondary result, as the berry-like swelling and sweet cell-sap persist to maturity; but such a result can hardly be described as a function, it is in fact incidental. When a modification sets in at so early a stage, and is so gradual in its accomplishment, it shows the initial cause must be more fundamental in character than a merely secondary result would demand, and it is more probably correlated with the function of the nutrition of the young ovule, as previously suggested.

The ground under the tree from which these strobili were collected was strewn with the Yew-like berries, and many were put up in formalin, both from the ground and from the tree, under the impression that they had been shed at maturity, but all were subsequently found to be in the prefertilization stage, as far as could be judged from the contracted prothallia.

Oliver, in a paper on the ovules of the older Gymnosperms (37, p. 455), discusses the fact that all the seeds of these plants preserved are in the stage just preceding fertilization, only occasionally being met with in an earlier state. He says :

'In the course of evolution, probably, the time of banding the integument was postponed till embryonic changes had set in, so that well-marked ovular or seed phases became very recognizable; but in the Palaeozoic seeds known to us, such a distinction can hardly be drawn. In referring to them the term seed is usually employed, though in recent Gymnosperms the corresponding stage would be called an unfertilized ovule. This usage in terminology has doubtless arisen from the appearance of maturity which their integumentary tissues present, a maturity which seems to preclude all possibility of subsequent expansion.'

The latter sentence might equally well have been written of the same stage in Podocarpus. Merely some enlargement in growth, progressive lignification of the tissue of the mesophyll and integument, and the loss of function in the resin canals, which apparently coincides with the cession of further vegetative growth, are the only vegetative features in the embryonic stages in these strobili, the ovuliferous scale being fully developed for protective purposes by the pre-fertilization stage.

Coulter and Chamberlain (18, p. 47) consider it possible that the Palaeozoic seed matured in developing a testa before fertilization, but becoming detached after pollination, developed a proembryo which subsequently aborted. Scott, in reviewing the above work (47, p. I $7 \mathrm{I})$ in 'Nature', says: 'The interesting question of the constant absence of an embryo in all Palaeozoic seeds hitherto investigated is discussed. This has been regarded as the normal condition, the development of the embryo not having begun until the seeds were shed, and then having passed over at once into germination. The author inclines to the view that all Palaeozoic seeds investigated were abortive, having been shed prematurely. The fact that nearly all the seeds observed were in the same stage of development, 
and the usual presence of normal pollen in the pollen chamber, scarcely seem consistent with this view.'

These conditions are also fulfilled in the modern Podocarps, as we have seen, as far as the shedding of the seed before or after fertilization, as quoted above. Such shedding may very well be due to altering conditions of temperature or water supply, or to unknown physiological conditions which demand a reduction in the number of fruits the sporophyte can mature. The demands of the purely vegetative tissues of the strobilus on account of the advanced organization of the ovuliferous scale is as great before fertilization as it is after; therefore, once initiated, the embryonic development is practically a fresh charge on the energies of the sporophyte.

\section{P. Hallii.}

$P$. Hallii is a scraggy, untidy looking tree, distributed over New Zealand, and is considered a variety of $P$. Totara by Pilger $(40$, p. 84$)$, who makes it var. Hallii, Pilg. Cheeseman (14, p. 648) keeps it up as a species, and this point of view, which would be supported by any botanist who had seen both species in the field, is also borne out by histological results.

The strobili occur singly in the axils of the lower foliage leaves of lateral shoots and consist of a short peduncle, and in material investigated apparently two bracts, of which one (P1. LI, Figs. 60, 61, 62, and Pl. LII, Fig. 64) or both may be fertile (Pl. LI, Fig. 63). The bract bases may remain either normal (Figs. 61, 62, and P1. LII, Fig. 64), or their bases become swollen (Pl. LI, Fig. 60). The ovule is very elongated, and may be as long (Fig. 60), or even longer than the bracts (Pl. LII, Fig. 64), or shorter (P1. LI, Fig. 6I) than the same.

Histology. The material, which was collected in March, shows embryo formation, but the exact stage could not be determined, as the prothallial tissues having dried to a certain extent, the paraffin in consequence could not penetrate sufficiently well for successful sectioning.

The ovuliferous scale shows a very much produced apex, equalling that seen in P. spicata (Fig. 62).

The two inverted bundles, running down from the tip, show no lateral branching in the lamina (Fig. 62, v.b.o.s.); each sends a phloem strand from the base of the ovule into the nucellus (Fig. 62,ph.st.). The resin canals are very large and no longer functional, all epithelium having disappeared.

This condition was also noted by Brooks and Stiles $(10$, p. 3 II $)$ in $P$. spinulosa, but to state that they are always functionless, as they infer, is judging cause from effect.

We have seen that in the earlier stages of the ovuliferous scale the resin canals are initiated with the vascular tissue system (P1.LIII, Fig. 77,r.c.), and invariably show a well-marked and active epithelium of thin-walled cells and dense contents (Pl. XLIX, Fig. $8 c$ ). Their constant presence and 
distribution (on the phloem or ventral side of the bundles) suggests that they play an important part in the very active metabolism of the ovuliferous scale, which controls the developing ovule. The complete organization of the former in the pre-fertilization stage, when even the lignification processes in the tissue of the same and of the integument have begun, also the metamorphosis of the bract bases, show how vital these rapid metabolic processes must be, as their action is so limited in period.

With the growth of the embryo the activity of the zone of tannin cells at the base of the integument and nucellus seems to cease, as in the first case the walls of the cells lignify, and in the second the entire tissue is digested by the rapidly growing $q$ gametophyte. The prothallus is about two-thirds its mature size at fertilization, and independently elaborates its own starch supplies for the nutrition of the embryo, merely drawing on the sporophyte for crude materials. The conveyance of supplies must be limited, once the nucellar tapetum no longer functions, to the phloem strands, which, as we have seen, penetrate the lignifying tissues (Pl. LIII, Fig. 72) in greater or less degree, through specialized areas. This secondary induration is different in form from that which obtains from about the pollination stage in the hypodermal cells at the apex of the integument. These cells are spirally thickened, the walls being very thick (Pl. LI, Fig. 57 a), and limited to a very small area.

The cells of the integument, on the contrary, show ordinary lignification of the walls with centripetal development, as seen in $P$. Totara, where in a young state only the peripheral layers were lignified, which had increased to half the tissue in the pre-fertilization stage, and it is evidently initiated in the zone of the nutrient tannin and starch cells as their available supplies are absorbed and their activity ceases.

In Fig. 62 a longitudinal section of the strobilus of this species shows three bracts, one of the upper pair fertile, and a lower sterile one, the presence of which was quite unnoticeable on examination before selection for embedding, and only revealed in the microtome series. Attention may also be called to the fact that, were the third bract placed decussately to the upper pair, the apex would not come into the radial section figured (Fig. 62, br. 3), but only the vascular strand seen, as figured in P. Totara (Fig. $5^{8,}$ tra. of 3 v.b.).

The tissue of the integument is entirely indurated and lignified, turning yellow with potash and red in phloroglucin. The nucellar tissue is crushed and empty (Fig. 62, muc.).

The megaspore membrane can still be traced, limiting the $f$ prothallus-indeed it peels off on disarrangement of the tissues; the prothallus cells are packed with starch, with an embryo about half the length of the prothallus in the centre, of which the exact stage could not be distinguished, the tissue having to a certain extent dried up. 


\section{P. nivalis.}

This species is a much branched erect or prostrate shrub, occurring in sub-alpine localities in New Zealand, from 2,000 to 5,000 ft. During a stay of four weeks at Mt. Cook, in the South Island, a serial collection of strobili was made, the species being very abundant about there. The material is in pollination stage, showing the breaking of nucellar tissue round the megaspore and vacuolization of the latter, and is in usually good condition.

The older shoots of this species seem to innovate, this year's strobili occurring singly in the axils of the lower leaves of this year's shoot (P1. LII, Fig. 65, strob.), whereas last year's, containing young embryos, would be on the next lowest portion, separated by the scars of the bud scales.

The fertile area on the young shoots is as well marked as in $P$. Totara (see p. 552).

The strobili consist of a short peduncle bearing two (Figs. 66 and 67 ) or three (Figs. 65 and 68 ) bracts, of which one (Figs. $65-7,69,70$ ) or two (Fig. 68) may be fertile. Pilger $(40$, p. 85$)$ for this species, as for P. Totara, gives only two 'scale leaves' with one ovule, but the two ovules were as often seen as not present, as were also the three bracts (Figs. 65 and 68); the presence of the third is sometimes indicated at maturity (Fig. 69), but often all evidence is lost in the basal swelling and fusion.

In $P$. nivalis the bracts, as usual in the Eupodocarps, are unmodified in the earliest stages (Figs. 66 and 67). It is on pollination that the bract bases begin to show distinct modification.

In the oldest or young embryo stage, as in $P$. Hallii, about an equal number of examples were seen with unmodified bracts (Figs. 70 and 71 ), which in this species are suffused with red from the pollination stages and probably before, but there is no glaucous bloom.

Where the bases do swell up they show the same colour and consistency so familiar to us in the Yew arils, and also characteristic of $P$. Totara and $P$. Hallii; and, similarly, all trace of the third bracts, where present, is lost, the blades being reduced to mere points.

Pl. LIII, Fig. $8 \mathrm{I}$ is a photomicrograph of a section taken through the apex of the integument, which is enclosed in the base of the ovuliferous scale. Two bundles are shown in the scale, as yet hardly organized, the ovule being in the homogeneous nucellus stage. The lamina of the fertile bract is seen to the left, and that of the sterile one to the right.

In this species the larger ovules were in the early embryo stage, with no cotyledons. The bract bases, however, were fully coloured and developed, as was the case with $P$. Totara (Pl. LI, Fig. 59) in the pre-fertilization stage, and P. Hallii (Fig. 63), in which the embryo was a little more advanced. In other instances the bracts remained unmodified (Pl. LII, Figs. 70 and $7 \mathrm{I}$ ), 
as described for P. Hallii (P1. LI, Fig. 6I and Pl. LII, Fig. 64). Sometimes a small dead ovule would be found still attached to the strobilus (Fig. 7 1).

The development of the species is so similar to $P$. Totara and P. Hallii that no longitudinal sections are given. The chief difference is in the micropyle, which is very long, which is also the case with the integument and the apex of the prothallus. The produced conical apex of the ovuliferous scale is intermediate between the two former species. Certainly in their development as in appearance, these three species seem to be very closely allied.

\section{Conclusions and Summary.}

In the foregoing pages we have seen that much of the debatable structure of the different parts of the fruiting axis in Podocarpus is due to interpretation based on the study of secondary modifications alone, which are easily explained by a serial study of the process of development in early stages.

The structure of the different parts of the cone is then homogeneous; therefore it is only by tracing the serial development of the axis as a whole from the bud to the fruit that the progressive sequence of the evolution of the structure and the specific development of its different parts can be offered.

This study at the same time strikingly reveals the relationship of the axis to the strobilus or cone of the Abietineae and its component parts, a relationship previously suggested by Bennett and Brown (2), Sperk (50), and Bertrand (3), and recently supported by Tison, in Saxegothaea (57).

These authors all consider the ovuliferous envelope of the Podocarpoideae as analogous with the ovuliferous scale of the Abietineae, which, to quote Bertrand (3), 'from the Abietineae to the Taxineae through Saxegothaea and the Podocarps shows a general tendency to surround in a hoodlike fashion the ovule or ovules which it carries, fusing more and more till finally it merges in the ovular integument in Torreya and Cephalotaxus'. Bertrand traces a further reduction in strobilus organization in the fewer number of bracts and increased independence of the ovuliferous scale for protective purposes, through Microcachrys and Dacrydium until the final reduction is reached in Podocarpus.

Tison has confirmed this interpretation for Saxegothaea, in which he considers the so-called aril of earlier botanists and the 'epimatium' of Pilger to be the ovuliferous scale of the other Conifers, the summit of which is developed to protect the ovule, the coalescence of the different parts of the female cone being less than in the other genera, where there is less development of the fertile bract above the ovule, whose base is partially protected by the ovuliferous scale. In other species of Podocarpus the bracts only develop below the ovule, which is encircled by the ovuliferous scale. 
Correlated with the gradual independence in function of the ovuliferous scale, we get a gradual change in the relation of the ovule to the scale.

In the Abietineae two ovules are placed at the base of the scale, one on each side, which is the most economic arrangement where the cone itself is organized for protective purposes. In Araucarineae one ovule is inserted medianly on the scale. In the Podocarpoideae, as Pilger has noted (40, p. I6), we get a gradual pushing up of the ovular rudiment on the 'epimatium 'or ovuliferous scale.

In Saxegothaea the apex of the ovuliferous scale is a homogeneous membrane, without vascular structure, merely protective in the pollination stages, the ovule being inserted towards the base of the bract and remaining free from the same, except at the base. The two inverted strands which supply the ovule are spoken of by Tison as the ovular supply; they are described as being without resin canals, and insert themselves on the vascular bundle of the bract at the base of the same, with a semi-rotation similar to that obtaining for the bundles of the ovuliferous scale in Podocarpus when they insert themselves between the bundles of the strobilus. It is impossible to draw any close comparison between Saxegothaea and Podocarpus in these respects, as the exact delimitation of the tissues of the ovuliferous scale and bract respectively are not insisted on.

From a cursory examination of Dacrydium (on which it is hoped to publish results later) it is possible that in that genus good intermediate series between Saxegothaea and Podocarpus will be found, showing the retrogression in the development of the fertile bract above the scale, and the increase in the protective function of the latter, which, however, does not fold round the highly inserted ovule, while on the other hand the coalescence of the different parts of the cone is still marked.

In Podocarpus we find a similar series, showing the course of reduction in the cone, the actual strobilus organization appearing only in the youngest stages, as subsequently the laminae of the bracts composing the cone do not develop further. The ovuliferous scale takes on an entirely independent organization, analogous to that of the foliage leaves, and completely surrounds and protects the ovule, which, as it grows up, it carries well above the bracts of the strobilus, the insertion of the ovule being towards the apex of the scale. This independent function is correlated with a great reduction in strobilus organization, the fertile bracts decreasing in number until they are limited to one or two in an apical position as the cone decreases in size and protective organization.

In Pilger's excellent monograph of the Taxaceae the Podocarpoideae are classified according to the progressive development of the 'epimatium', which he regards as an accessory organ, a ligula-like excrescence of the 'carpel', through Microcachrys, Saxegothaea, and Dacrydium to Podocarpus, in which family this organ reaches its maximum development. 
It is interesting to note that this arrangement accords completely with the views of the authors quoted above, and also with the results of the present work on Podocarpus, as progressive development of the ovuliferous scale is correlated in each stage with reduction in strobilus formation.

The systematic position therefore remains on Pilger's basis, by merely substituting ovuliferous scale for ' epimatium'.

Morphologically the results may be summarized as follows:

In Podocarpus, in the youngest phases, a strobilus formation obtains which is masked by subsequent modification.

An actual series of successive stages in the reduction of the strobilus is apparent in the different sections of the family.

In $\S$ DACRYCARPUS the peduncle is clothed with scale leaves, in spiral sequence, which show increase in size just below the strobilus.

The strobilus is reduced to two to five bracts, of which one to three may be fertile.

In these bracts, which are more or less unmodified in the younger stages, the bases show subsequent swelling and coalescence, ultimately changing colour, but the laminae remain green and unaltered.

The lamina of the fertile bract is fused with the ovuliferous scale to the apex of the latter, showing the cohesion between the scale and the supporting bract seen in Microcachrys and Saxegothaea, as also in Agathis, Araucaria, and the Abietineae.

In $\S$ DACRYCARPUS this fusion may be complete, as in $P$. dacrydioides, or sometimes incomplete, as in $P$. imbricata, where the apex of the fertile bract often remains free, and may even exceed that of the scale.

The ovuliferous scale entirely enfolds the ovule, leaving an orifice at the micropylar end where the integument protrudes on pollination; but subsequent growth in the lamina of the scale, and swelling at the base of the same on the ventral surface, cause the micropyle to be pressed against the lower portion of the scale, closing up the orifice.

In $\S$ NAGEIA (if $P$. vitiensis can be taken as typical of that section) and $\S$ STACHYCARPUS the peduncle (branched in the former) is still clothed with scale leaves, showing increase in size below the strobilus.

The strobilus consists of eight to ten bracts, of which all, or only one or two of the apical ones, are fertile. These bracts are fleshy and strap-like in the youngest stage, and opposite and decussate in arrangement. There is no subsequent swelling of the bases, and the laminae may be shed on or before fertilization, leaving only scars, which show a spiral sequence, due to elongation of the axis.

The lamina of the ovuliferous scale develops quite independently of the lamina of the fertile bract, which enfolds and protects the former in the youngest stages, but either remains undeveloped as a ring at the base, or is subsequently shed, 
$\S$ EUPODOCARPUS offers the greatest extreme in the reduction of the strobilus in the genus, from the point of view of number of members, but the cone-like organization is nevertheless obvious in the young stages.

The peduncle is naked, and the bracts of the strobilus may be reduced to two. In some species the two lower retain the strap-like unmodified form we get in $\$$ STACHYCARPUS, and are merely protective in the young stages, being subsequently shed as in that section. In $P$. spimulosa $(40$, p. 77$)$ the bases often swell up like those of the upper bracts. In other species they are finally eliminated altogether.

The upper bracts, of which one or two are fertile, are unmodified and protective in the young stage, but their bases soon swell and become coloured as in $\S$ DACRYCARPUS ; the laminae, however, do not persist, as in that section, but become entirely merged in the basal swelling, all subsequent development being arrested.

The secondary swelling and coloration of the bract bases in some cases is already present in the pre-fertilization stage; its presence can therefore be of no use to the plant in the dissemination of seeds, as stated by Pilger, but is probably correlated with ovular development by serving as water-storage tissue.

The ovuliferous scale is well protected by the sterile bracts in the young stages, but gradually rises above them until, on pollination, the lamina of the fertile bract alone encircles the base as a ring, remaining stationary in development. The ovuliferous scale takes on not only the whole protective covering of the ovule, but by the early and complete organization of its metabolic activities supplies the material for the development of the ovule as well.

Judging from the stages obtained in the material collected, development occurs in the early spring. In Fiji this season is in August and September, and material collected in those months showed pollination and young embryo stages. In New Zealand at the same season, in September and October in the North Island, $P$. ferruginea and $P$. Totara showed pollination and post-pollination stages and pre-fertilization. In the South Island, at Mount Cook, at an altitude of $2,500 \mathrm{ft}$., $P$. nivalis showed pollination to young embryo stages in December and January, while further south, at Glade House in March or autumn, $P$. Hallii was found in the embryo stage.

At Buitenzorg, enlarging megaspore and pre-fertilization stages were found associated in December, and on other trees embryos, mature and immature, were also collected.

As is the case with the Abietineae, last year's cones were generally found concurrently on the old wood with those developed on this year's wood above them.

There is a very marked uniformity in the stages of development of the 
ovules in the strobili of each period. It is probable that this feature is associated with the great reduction in the number of fertile bracts to each cone. The same fact has been recorded for Ginkgo.

\section{Histological Results.}

The ovuliferous scale shows the complete organization of a foliage leaf with epidermis, stomata, and mesophyll tissue. It is provided with a welldeveloped vascular system with inverted orientation, and accompanied by resin canals.

In $\S$ DACRYCARPUS a hypodermal sclerotic layer is present in both the ovuliferous scale and the foliage leaves.

In $\S$ STACHYCARPUS, on pollination, groups of stone cells form a regular zone in the mesophyll tissue. In P.ferruginea these were also present in the foliage leaves.

The cells of the mesophyll show secondary thickening throughout the group, which is initiated before fertilization.

The vascular system of the ovuliferous scale consists of two bundles ( $P$. vitiensis four), each accompanied by a resin canal. These arise each at the extreme apex of the scale in a hypodermal group of tracheides, as is also the case in the foliage leaves. They branch in a ring below the insertion of the ovule, half-way down the scale. From this ring secondary branches may run into the lamina of the scale, so encircling the ovule; these branches stop half-way down the lamina or continue right to the micropyle, and are always terminated by groups of tracheides.

Below the ovule the main bundles separate, and by a gradual semirotation the phloem becomes peripherally placed when they insert themselves, one on each side of the vascular strand of the fertile bract, on to the ring of bundles in the strobilus.

Resin canals accompany each bundle on the phloem side. These are very active, with well-developed epithelium, and evidently play an important part in the metabolism of the scale. Their function gradually ceases on the organization of starch formation in the female prothallus. In later embryo stages the epithelium is no longer traceable.

The resin canals limit the tissue of the integument in the plane of the mesophyll tissue of the scale.

The integument shows basal growth, and its small regular cells stand out well from the irregular mesophyll of the scale. Long lignified hypodermal cells are differentiated in the apex, at the micropyle, at pollination, at which stage also a nutritive zone of starch and tannin cells (cellules tanniferes of Tison) is laid down round the base and sides of the nucellus till the prothallus is fully organized, when, as is the case with the resin canals, the 
function of these cells apparently ceases and the walls gradually lignify, areas being left where phloem strands penetrate to the nucellus.

In $P$. ferruginea these tannin cells are organized in regular superposed layers, laterally elongated, which surround the integument.

The nucellus, composed of larger and less compact cells, is also characterized by a smaller zone of tannin cells. Before pollination the apex shows rows of loose stigmatic cells, which catch the pollen-grains. These cells subsequently become crushed on the elongation of the tubes; the latter are often exposed in consequence.

No pollen-grains or cases of penetration by pollen-tubes were observed from any portion of the nucellus other than the stigmatic apex.

In $\S$ NAGEIA and $\S$ STACHYCARPUS, also some species of $\S$ EuPoDoCARPUS, the apex of the nucellus is very much elongated.

From the pollination stages starch is present in the cells of the apex in all species, and the walls often show thickening.

A well-differentiated tapetum of several layers is present in all the species examined, the cells with active nuclei and denser contents showing continuous disintegration in the outer layer, from the development of the megaspore to the absorption of the body of the nucellus by the female gametophyte.

Tetrad formation was not seen.

In megaspore formation the nucleus divides, a parietal layer of free nuclei surrounding the central vacuole, which gradually fills up with prothallial tissue. Further stages were not traceable, owing to contraction of tissue, but are evidently paralleled with Coker's results on $P$. coriacea and similar development in the Abietineae.

A megaspore membrane of two layers was observed in all the species surrounding the developing prothallus, which persists till the embryo stages. In $P$.polystachya it was not traceable with certainty in the embryo stage.

The female prothallus at fertilization consists of a central cylinder of small elongated and rectangular cells, and large, mostly binucleate, polygonal cells extending to the periphery, and it is limited by an epidermal layer of small uninucleate cells, with denser contents and active nuclei.

The number of archegonia seen was five to seven.

The archegonia, arranged in one or two groups, are very long and flaskshaped. The neck consists of two to six cells, and they are each surrounded by a single layer of jacket cells.

In one case two archegonia were enclosed in one jacket.

No ventral canal cell was seen.

Sterile prothallia, with a cavity replacing the archegonia, were observed. In one case no tracheides were present, but on two occasions well-developed tracheides were found in the central cylinder of small-celled tissue. 
A complex of proembryos with suspensors forms a cavity at the apex of the prothallus. One suspensor develops an embryo which penetrates the central cylinder. Starch formation is initiated in the central cylinder cells immediately below the embryo, and mitotic divisions occur in the cells. The two divisions must follow one another in rapid succession, as four daughter nuclei are generally seen enclosed in the same limiting membrane. These nuclei further divide up to eight, remaining active and normal even when the cells are packed with starch.

The cavity formed by the complex gradually closes up as the embryo increases in size. Resin canals surround the plerome cylinder before the cotyledons are differentiated, and appear in their tissue as soon as the latter develop.

In the mature embryo the root-cap extrudes through the apex of the prothallus.

The cortical tissues of the embryo are packed with starch, but none is seen in the cells of the plerome cylinder.

The structure of the hypocotyl is that of a diarch root, and has two areas of primary bast alternating with two poles of the protoxylem, showing spiral vessels. Two branches from each pole pass to each cotyledon.

Resin canals are present in the root-cap, hypocotyl, and pith of the mature embryo.

The acquisition of a considerable quantity of material in various young stages has rendered it possible for the first time to bring forward a certain amount of evidence in favour of the view that in Podocarpus we are dealing with a much modified cone. The cone character is well seen at an early stage, but subsequent developments, including the swelling of the bract bases at the expense of the lamina, or the shedding of the latter and the great development of the ovuliferous scale, together with the reduction in the number of fertile members (usually only one), completely mask the strobilus organization. This view was formulated by Bennett and Brown (2) as early as $I 838$, and later by Sperk (50) and Bertrand (3), and quite recently by Tison (57), working on Saxegothaea. With the exception of Tison these authors were limited to herbarium material.

In conclusion, my thanks are due in New Zealand to Mr. T. F. Cheeseman, Curator of the Auckland Museum, for most useful data on localities and seasonal developments, and also for the inestimable aid rendered by his admirable 'Manual of the New Zealand Flora'; to Mr. F. Grey, of Nelson, for his indefatigable kindness in arranging expeditions in that district, of which his steady botanical exploration has given him an unrivalled knowledge; and to Professor Charles Chilton, of Christchurch, for his kindness in allowing me to avail myself of laboratory facilities at the University to test material obtained. 
I must also express my indebtedness to Herr H. J. Wigman, the Director of the Botanic Gardens at Buitenzorg, for material obtained from the gardens, and for facilitating my stay at Tsjibodas; also to Mr. H. N. Ridley, F.R.S., C.M.G., Director of the Botanic Gardens at Singapore ; and finally to Professor J. B. Farmer, F.R.S., for his great kindness and the invaluable facilities afforded me at the Royal College of Science during the course of this investigation.

\section{REFERENCES.}

1. Baillon, H. : Organogénie florale des Podocarpus. Association française, $2^{\mathrm{e}}$ Sess., Lyon, 1873 , pp. 505-9, Pl. VIII.

2. Bennett and Brown, R. : Planteae jav. rar. 1838 .

3. Bertrand, M. C. E. : Étude sur les téguments séminaux des végétaux phanérogames gymnospermes. Ann. Sc. Nat., Bot., $6^{\mathrm{e}}$ sér., vii, 1878 , pp. 57-92.

4. Blackman, V. H.: On the Cytological Features of Fertilization and Related Phenomena in Pinus silvestris, L. Phil. Trans. Roy. Soc., London, B., vol. I90, I896, pp. 395-426, Pl. XII-XIV.

5. Blume, - : Enum. Pl. Javi, i827.

6. - Rumphia, III., I 847 .

7. Braun, A.: Das Individuum der Pflanze. Berlin, $\mathbf{1} 853$.

8. - Ueber eine Missbildung von Podocarpus Chinensis, \&c., in Monatsber. K. P. Acad. d. Wiss., Berlin, I869, pp. 238-66.

9. Brongniart et Gris : Sur quelques Conifères de la Nouvelle-Calédonie, in Ann. Sci. Nat., Bot., $5^{\mathrm{e}}$ sér., vi, 1866, pp. ${ }^{2} 3^{8-266 .}$

10. Brooks, F. T., and Stiles, W.: The Structure of Podocarpus spinulosa, (Smith) R. Br. Ann. Bot., xxiv, I910, pp. $30^{5}-18$, Pl. XXI.

11. Brown, R.: General Remarks on the Botany of Terra australis. Misc. Bot. Works., i, I866.

12. Carrière, A. R. : Traité général des Conifères. Ed. 2, Paris, I867.

13. Celakovsky, L. J. : Nachtrag zu meiner Schrift über die Gymnospermen. Eng. Bot. Jahrb., xxiv, pp. 202-3I.

14. Cheeseman, T. F.: Manual of the New Zealand Flora. Wellington, igo6.

15. Coker, W. C.: On the gametophytes and embryo of Podocarpus. Bot. Gaz., xxxiii, 1902, pp. 89-IO7, Pl. V-VII.

16. $:$ On the gametophytes and embryo of Taxodium. Bot. Gaz., xxxvi, Iyo3, pp. I-27, II $4-40, \mathrm{Pl}$. I-XI.

17. $:$ Fertilization and Embryogeny in Cephalotaxus Fortunei. Bot. Gaz., xliii, 1907, pp. I-IO, Pl. I.

18. Coulter and Chamberlain : Morphology of Gymnosperms. Chicago, igio.

19. Eichler, A. W. : in Mart. Fl. Bras., I 863.

20. - Blüthen-Diagramme, I., I875.

21. $:$ in Engler und Prantl, Pflanzenfam., II, i, I889.

22. Endlicher, S.: Genera Plantarum, 1840.

23. : Synopsis Coniferarum, 1847 .

24. Favre, E. : Recherches sur la fleur femelle du Podocarpus sinensis, in Ann. Sci. Nat., Bot., $5^{\text {e }}$ sér., iii, I $86_{5}$, pp. 379-82.

25. Gerry, Eloise : The Distribution of the 'Bars of Sanio' in the Coniferales. Ann. Bot., xxiv, I9I0, pp. I I 9-23, Pl. XIII.

26. Gibbs, L. S. : A Contribution to the Montane Flora of Fiji, with Ecological Notes. Journ. Linn. Soc. Bot., xxxix, I909. 
27. Hooker, W. J. : Bot. Mag., Pl. 4655,1852 .

28. Lawson, A. A.: The Gametophytes, Archegonia, Fertilization, and Embryo of Sequoia sempervirens. Ann. Bot., xviii, I904, pp. I-28, Pl. I-IV.

29. - The Gametophytes and Embryo of the Cupressineae, with special reference to Libocedrus decurrens. Ann. Bot., xxi, I907, pp. 28I-30I, P1. XXIV-XXVI.

30. : The Gametophytes and Embryo of Sciadopitys verticillata. Ann. Bot., xxiv, I9IO, pp. 403-2I, Pl. XXIX-XXXI.

31. L'Héritier, - : in Pers. Syn., ii, 580 , I807.

32. Lloyd, Francis E.: Vivipary in Podocarpus. Torreya, ii, 1902, pp. 113-17, Fig. 3.

33. Miyake, K. : Contribution to the Fertilization and Embryogeny of Abies balsamea. Beih. Bot. Centralbl., xiv, I903, pp. I34-44, P1. VI-VIII.

34. - The Development of the Gametophytes and Embryogeny in Cunninghamia sinensis. Beih. Bot. Centralbl., xxvii, I9I I, pp. I-25, Pl. I-V.

35. - and Yasui, K.: On the Gametophytes and Embryo of Psevdolarix. Ann. Bot., xxv, I9II, pp. 639-47, Pl. XLVIII.

36. Norén, C. O.: Zur Kenntniss der Entwicklung von Saxegothaea conspicua, Lindl. Svensk. Bot. Tidskr., II, I908, pp. IoI-22, Pl. VII-IX.

37. Oliver, F. W.: The Ovules of the older Gymnosperms. Ann. Bot., xvii, I903, pp. 45I-76, Fig. 20, P1. XXIV.

38. Parlatore, F.: Studi organografici sui fiori e sui frutti delle Conifere. Firenze, i864.

39. Payer, - : Familles naturelles des plantes. Paris, i860.

40. Pilger, R. : Taxaceae, in Engler's Das Pflanzenreich, iv, I903.

41. Richard, L. C. and A.: Comment. Bot. Conif. et Cycad. Stuttgart, I826.

42. Saxton, W. T. : Preliminary Account of the Ovule, Gametophytes, and Embryo of Widdring. tonia cupressoides. Bot. Gaz., xlviii, I909, pp. I6I-78, Pl. XI.

43. - Contributions to the life history of Widdringtonia cupressoides. Bot. Gaz., June, I9IO, pp. 3I-48, Pl. I-III.

44. 69, Pl. XLV, XLVI.

45. SACHS, J. : Lehrbuch der Botanik. Ed. 4, Leipzig, I874.

46. Schumann, K. : Ueber die weiblichen Blïten der Coniferen, in Verh. Bot. Ver. Prov. Brandenburg, xliv, I9०3, pp. 5-80.

47. Scotт, D. H. : Nature, Aug. Iо, I9I I, p. I II.

48. Seemann, Berthold : Flora Vitiensis. London, i $865-73$.

49. Solander, - : in Hort. Kew. ed., i, iii, i 789.

50. Sperk, G.: Die Lehre von der Gymnospermie, etc., in Mém. Acad. Imp. Sci. St. Pétersb., $6^{\ominus}$ sér., xiii, I869, pp. I-9I, Pl. I-VII.

51. Stopes, M. C., and FUjII, K.: The nutritive relations of the surrounding tissues to the Archegonia in Gymnosperms. Beih. Bot. Centralbl., xx, I906, pp. I-24, Pl. I.

52. Strasburger, E.: Die Coniferen und die Gnetaceen. Jena, i 872.

53.

54. Thomson, R. B. : Preliminary Note on the Arancarineae. Science, N.S., xxii, I905, p. 88.

55. - : The Megaspore Membrane of the Gymnosperms. Univ. Toronto, Biol. Ser. 4, I905, pp. 3-64, Pl. I-V.

56. 1909, pp. $345^{-54}, \mathrm{Pl}$. XXII-XXV.

57. Tison, A.: Sur le Saxe-Gothaea conspicua, Lindl. Mém. Soc. Linn. Normandie, xxiii, 1909, pp. I39-60, Pl. IX, X.

58. Van Tieghem, - : Anatomie comparée de la fleur femelle des Cycad., Conif., Gnetac., in Ann. Sci. Nat., Bot., $5^{\mathrm{e}}$ sér., x, I869, pp. 269-304, Pl. XIII-XVI.

59. Conifères. Bull. Soc. Bot. France, xxxviii, I 891 , pp. $162-76$.

60. Worsdell, W. C.: The Structure of the Female 'Flower' in Coniferae. Ann. Bot., xiv, I900, pp. 39-82.

61. Young, Mary S.: The Morphology of the Podocarpineae. Bot. Gaz., 1, I910, pp. 8I-100, Pl. IV-VI.

62. Natho Rst, A. G.: Paläobot. Mitt. Kungl. Svens. Vetenskapak. Hand. 43, 8, pp. 3-20, Pl. I-III. 


\section{EXPLANATION OF PLATES XLIX-LIII.}

Strob., strobilus; ped., peduncle ; s., scale; bud s., bud scales; l., leaf; s.l., scale leaves; br., bract ; $s . b r$., sterile bract; f.br., fertile bract; $b . b r$., base bract; lam., lamina; $a p$. bud, apical bud; $a p$., apex ; o. s., ovuliferous scale; mic., micropyle; $i$, integument ; nuc., nucellus; $o$., ovule ; v. b.f. $b r$., vascular bundle, fertile bract; v. b. o.s., vascular bundle, ovuliferous scale ; $x$., xylem; ph., phloem; ph. str., phloem strands ; tr., tracheides; r.c., resin canal ; mes., mesophyll ; $c$., cells ; stone c., stone cells ; st., starch ; $t$., tannin ; $h . f$., hypodermal fibres ; $e_{0}$, epidermis ; stom., stomata ; idio., idioblasts ; tis., tissue ; lig., lignified ; m.m., megaspore membrane ; pro., prothallus ; meg., megaspore ; tap., tapetum ; arch., archegonia ; in., initials ; n., nucleus; e.n., egg nucleus; $j . c$. , jacket cells ; $n . c$. , neck cells; $p . g$., pollen-grain; $p . t$., pollen-tube; nuc. cap, nucellus cap; pro. emb., proembryos; sus., suspensor; cen. cyl., central cylinder; dig.c., digested cells; cots., cotyledons; pl., plerome; plu., plumule; hyp., hypocotyl ; rt. cap, root-cap; pro. cam. str., procambium strands ; cor., cortex ; stig. ap., stigmatic apex; gen.n., generative nucleus; stalk n., stalk nucleus ; tube n., tube nucleus ; cup.l., cupressoid; imb., imbricate ; epi., epithelium.

\section{PLATE XLIX.}

Fig. I. P. imbricata. Branch showing strobili in two stages: this year's with unmodified bracts, in early pollination stage; last year's with bract bases swollen at the expense of the lamina, in pre-fertilization stage. Nat. size.

Fig. 2. Strobilus with two bracts, each fertile; bract bases swollen and verruculose; scale leaves subtending strobilus removed. $\times I 6$, red. $\frac{1}{2}$.

Fig. 3. Strobilus with two bracts, one fertile; showing the apex of the fertile bract unusually free and prolonged, and larger size of the scale leaves of the peduncle immediately subtending the strobilus. $\times 16$, red. $\frac{I}{2}$.

Fig. 4. Strobilus with four bracts, one fertile, with apex still free, in fertilization stage; the peduncle is covered with imbricating scale leaves, those subtending the strobilus showing less modification as the latter increases in size. $\times 8$, red. $\frac{\mathrm{I}}{2}$.

Fig. 5. Sterile strobilus, showing base of ovuliferous scale swollen and verruculose (Singapore). $\times 8$.

Fig. 6. Longitudinal section through ovuliferous scale and ovule in pre-fertilization stage, showing lamina of fertile bract, with normal vascular bundle, fused with the lamina of the scale, with inverted vascular system, both enclosing the ovule; epidermis, hypodermal layer of fibres, and mesophyll with lignified idioblasts are continuous for both; the integumental tissue is limited by the resin canals and shows a zone of nutritive cells, i.e. tannin and starch; lignified cells occur in the apex, at the micropyle; the nucellus shows also a zone of nutritive cells, and starch is deposited in the cells of the apex; a tapetum showing continual breaking down of tissue limits the nucellus on the inside; the female gametophyte is invested by a two-layered megaspore membrane, and shows archegonia ; the cells of the prothallus are binucleate. $\times 16$, red. $\frac{1}{2}$.

Fig. $6 a$. Archegonium with contracted protoplasm and resting egg nucleus, showing neck cells at apex, surrounded by jacket cells. $\times 625$.

Fig. 66 . Two archegonia in one jacket, seen in a prothallus of another species. $\quad \times 625$.

Fig. 6 c. Idioblasts in mesophyll tissue.

Fig. 7. Strobilus with two bracts, one fertile, from the subsummit zone of Kinabalu (I I ,500 ft.), in which the scale leaves do not spread out below the bracts, as in Fijian and Buitenzorg material; pollination stage; the apex of the lamina of the fertile bract projects above the ovuliferous scale. $\times 16$, red. $\frac{1}{2}$.

Fig. 8. Longitudinal section of strobilus in pollination stage or after; the fertile bract shows distinct apex, which becomes obscured as ovule matures; the nucellus is contracted, but pollen-tubes can be traced in the apex. $\times 16$, red. $\frac{1}{2}$.

Fig. $8 \mathrm{a}$. Hypodermal layer of fibres in the lamina of the fertile bract and that of the ovuliferous scale, with epidermis. $\times 625$.

Fig. 86 . Verruculose outgrowths on the swollen bract bases, the epidermis showing tannin contents; no hypodermal layer of fibres. $\times 625$. 
Fig. $8 c$. Resin canal with epithelium of thin-walled cells with active nuclei and darker staining contents, surrounded by cells containing tannin and starch. $\times 625$.

Fig. 9. P. dacrydioides. Longitudinal section of pollination stage; tannin and starch cells show at the base of the integument and nucellus, with starch in the apex of the latter, and a well-marked tapetum limiting on the inside; megaspore shows dividing nuclei. $\quad \times 16$, red. $\frac{1}{2}$

Fig. Io. Peduncle with imbricating scale leaves, terminated by strobilus of three bracts, one fertile, the lamina of which is fused with the ovuliferous scale. $\times 8$.

Fig. II. Strobilus showing two bracts, one fertile, older stage. $\quad \times 8$.

Fig. I 2. Strobilus of three bracts, one fertile. $\times 8$.

Fig. I3. Longitudinal section of above stage: the prothallus is contracted, but shows centripetal filling by free nuclear division. $\times 16$, red. $\frac{1}{2}$.

Fig. I4. $P$. vitiensis, showing position and branching of peduncles, each branch bearing a strobilus with one fertile bract; the ovules are in the fertilization stage, the upper ones on simple peduncles being younger. Nat. size.

Fig. I5. Young strobilus, showing peduncle with imbricating scale leaves; the strobilus is composed of five pairs of bracts, opposite and decussately arranged, with one of the upper pair fertile ; the lamina of the fertile bract is free from the ovuliferous scale, which bears an ovule with undifferentiated nucellus. $\times 16$, red. $\frac{1}{2}$.

Fig. I6. Peduncle with eight bracts, of which the upper two are fertile; the ovuliferous scales bearing the ovules have grown far above the lamina of the fertile bracts; these laminae, with those of the sterile bracts, subsequently desiccate and fall off, leaving only the elongated bract bases, as in the last species, which remain unmodified; fertilization stage. $\times 16$, red. $\frac{1}{2}$.

\section{PLATE L.}

Fig. I7. Longitudinal section of above stage, showing the growth of the lamina of the ovuliferous scale, that of the fertile bract remaining stationary; the prothallus shows contraction, but archegonia are traceable in its tissue : $\delta$ prothallia show above the archegonia, the stage being just prior to fertilization. $\times 16$, red. $\frac{1}{2}$.

Fig. I8. Male prothallus with pollen-tube, which has penetrated the unusually long apex of the nucellus, showing two generative nuclei, with stalk and tube nucleus. $\times 245$.

Fig. I9. P. spicata. Bbranch showing strobili in the axils of the foliage leaves. Nat. size.

Fig. 20. Strobilus bearing three fertile tracts, showing bud scales at base, and modified foliage leaves above, which are succeeded by the fertile bracts and an apical bud. $\times 16$, red. $\frac{1}{2}$.

Fig. 2I. Strobilus of which the apical bud has been damaged, leaving only a cicatrized scar; this fact has probably stimulated the development of the modified leaves into foliage leaves; one fertile tract on the shoot. $\times 16$, red. $\frac{1}{2}$.

Fig. 22. Longitudinal section of strobilus, showing produced apex of ovuliferous scale. A regular zone of stone cells occurring in groups of two or three is seen in the mesophyll; phloem strands penetrate to the nucellus, and the vascular bundles send secondary branches into the lamina of the scale; the prothallus shows contraction, but free cell-division can be traced. $\times 16$, red. $\frac{1}{2}$.

Fig. 22 a. Section through micropyle, showing non-septate closing cells. $\times 625$.

Fig. 23. Stone cells in the mesophyll of the ovuliferons scale. $\times 625$.

Fig. 24. P. ferruginea. Strobilus with peduncle in the axil of a foliage leaf; the fertile bract slightly covers the ovuliferous scale; pollination stage. $\times 8$.

Fig. 25. Strobilus in younger stage with scale leaves dissected off the peduncle; the bracts are still folded and protect the ovule enclosed in the scale; the nucellus is undifferentiated. $\times 16$, red. $\frac{1}{2}$.

Fig. 26. Strobilus and peduncle still enclosed in the scale leaves investing the latter. $\times 16$, red. $\frac{1}{2}$.

Fig. 27. Peduncle bearing strobilus composed of six pairs of bracts, of which one of the uppermost pair is fertile; the ovuliferous scale shows above the bract; scale leaves clothe the peduncle. $\times 16$.

Fig. $27 a$. Ventral view of same, showing micropyle. $\times 16$, red. $\frac{1}{2}$.

Fig. 28. Strobilus with two fertile bracts; ovuliferous scale has grown up above the bracts, of which only the bases persist, the laminae having shrunk to pin points; scars indicate the sterile bracts, of which the laminae have already been shed; pre-fertilization stage. $\times 8$, red. $\frac{1}{2}$. 
Fig. 29. Longitudinal section of strobilus slightly older than above stage; phloem strands penetrate to the nucellus from the vascular bundles; the tannin cells of the integument show a symmetrical, laterally elongated arrangement ; pollen-tubes have penetrated half-way down the apex of the nucellus, and the very contracted prothallus shows cell-wall formation; a scar is all that remains of the lamina of the fertile bract; in section the arrangement of the bracts in the strobilus is seen to be more spiral than opposite and decussate, as the morphology would suggest. $\times 8$, red. $\frac{1}{2}$.

Fig. 3o. P. elata. Earliest stage, showing strobilus of four bracts, the lower pair being narrower than the upper, of which one is fertile; all four enclose the ovuliferous scale. Ventral view, the opposite sterile bract having been removed. $\times 16$.

Fig. $30 a$. Dorsal view of fertile bract, showing unmodified lamina and base. $\times 16$.

Fig. 31. Older stage, ovuliferous scale showing above the bracts, which are becoming broader and thicker. $\times 16$.

Fig. 3I $a$. Lateral view, showing both upper bracts, with the lower pair dissected off. $\quad \times$ I 6 .

Fig. $3 \mathrm{I} b$. Ventral view of same, showing micropyle. $\times$ I 6.

Fig. 32. Strobilus showing lower bracts which remain undifferentiated; the upper pair show shrinking laminae and swollen bases. Pollination stage. $\times$ I6.

Fig. $32 a$. Ventral view of above, showing sterile bract cut off, to expose micropyle. $\times 16$.

Fig. 33. Strobilus with ovule showing young embryo; the unmodified bracts still persist, the upper bracts show very swollen bases and laminae shrunk to points; the ovuliferous scale extends above the fertile bract. $\times 16$, red. $\frac{1}{2}$.

Fig. 34. Group of tracheides terminating a vascular bundle in the lamina of the ovuliferous scale. $\times 625$.

Fig. 35. P. polystachya. Strobilus with ovule, showing embryo; the unmodified lower bracts have been shed and in the upper ones all foliar structure is lost, the lamina being no longer indicated, while the bases are fused in a succulent whole. Nat. size.

Fig. 36. Longitudinal section of prothallus, showing complex of proembryos, one being formed from each archegonium; the suspensor bearing successful embryo is seen penetrating the central cylinder of prothallus, the cells of which are binucleate, and those immediately below the embryo show dense starch contents. $\times 245$.

Fig. 37. Longitudinal section of prothallus, showing embryo increasing in size at the expense of the central cylinder; the remains of the suspensor tubes are still traceable, also the cavity formed by proembryos, with disorganized remains of complex; contraction of tissue is shown at the apex of the prothallus, causing the epidermal layer to fold in and out. $\times 16$.

\section{PLATE LI.}

Fig. 38. Longitudinal section of ovule enclosed in the ovuliferous scale, showing stone cells scattered in the mesophyll of the latter, also laminal branching of the vascular bundles; the integument shows lignification of the cell-walls and the nucellus is reduced to the apex, which, still showing starch and pollen-tube, forms a mere cap; the prothallus has grown at the expense of the nucellar tissue, and shows an undifferentiated embryo ; the cavity left by the complex of proembryos has almost closed, though still filled with the crushed remains; digested cells surround the embryo, and the crushed and empty tissue of the cells of the central cylinder is being pushed down as a plug by the vertical growth of the embryo. $\times 16$, red. $\frac{1}{2}$.

Fig. 39. Longitudinal section of embryo, showing differentiation of the cotyledons, root apex, and resin canals ; the dotted area shows the relative distribution of starch in the prothallus, of which the cells, excluding the peripheral layer, are multinucleate. $\times 8$, red. $\frac{I}{2}$.

Fig. $39 a$. Multinucleate cells of the prothallus, packed with starch grains. $\times 625$.

Fig. 39 b. Peripheral layer of the prothallus, with megaspore membrane. $\times 6_{25}$.

Fig. 40. Nucleus in prothallial cells, on initiation of division, showing four daughter nuclei still enclosed in the limiting membrane, as seen in Fig. $3^{6}$, in the cells of the central cylinder, just below embryo. (L. Digby del.)

Fig. 4I. Sterile strobilus borne on same tree as the fertile one drawn in Fig. 35. Nat. size.

Fig. 42. Longitudinal section of above. In this prothallus, which contains no starch, tracheides are developed in the central cylinder; a cavity occurs where the archegonia would normally be found. $\times$ I6. 

$\times 625$

Fig. 43. Tracheides as seen in the central cylinder of small-celled tissue of sterile prothallus.

Fig. 44. P. bracteata. Mature strobilus, with swollen bract bases, deep purple in colour (Buitenzorg). Nat. size.

Fig. 45. Longitudinal section of embryo, showing cotyledons, with plerome cylinder and cortical resin canals. $\times 8$, red. $\frac{1}{2}$.

Fig. 46. Longitudinal section through prothallus, showing embryo with extruding root-cap; in the embryo resin canals occur both in the cortex and the pith; procambium strands of spiral vessels mark the plerome cylinder; the cotyledons show similar development, each being served with two vascular strands. $\times 8$, red. $\frac{\mathrm{I}}{2}$.

Fig. 47. Embryo dissected out. $\times 8$, red. $\frac{1}{2}$.

Fig. 48. P. neriifolia. Strobilus in earliest stage available, with four bracts, one of which is fertile; the lowest pair of unmodified bracts have been cut off, showing two pairs of upper bracts, apparently opposite and decussate (Fiji). $\times 8$, red. $\frac{I}{2}$.

Fig. 49. Later stage, strobilus with three bracts, one of which is fertile, showing approach to spiral arrangement. $\times 8$, red. $\frac{1}{2}$.

Fig. 50. Strobilus of three bracts, of which two are fertile; the caducous lower bracts have already been shed; the upper ones show shrunken laminae and swollen bases. $\times 8$, red. $\frac{1}{2}$.

Fig. 5I. Fertilization stage. Nat. size.

Fig. 52. P. saligna, showing a strobilus of three bracts, of which one is fertile; the peduncle, in this species, is very elongated. $\times 8$, red. $\frac{1}{2}$.

Fig. 53. Basal portion of a strobilus with four bracts, showing a modification of the decussate arrangement. $\times 8$, red. $\frac{1}{2}$.

Fig. 54. P. Totara. Strobilus of three bracts, still undifferentiated, one of which is fertile; ovule in pollination stage. $\times 8$.

Fig. 55. Strobilus of four bracts, two of which are fertile; the oldest ovule shows nuclear division in macrospore. $\times 8$.

Fig. 56. Strobilus with three bracts, of which two are fertile; the oldest ovule shows free cell formation in the prothallus. $\times 8$.

Fig. 57. Longitudinal section of Fig. 55, showing well-differentiated tapetum and enlarging macrospore. $\times 16$, red. $\frac{1}{2}$.

Fig. 58. Longitudinal section of a strobilus with three bracts; in the largest ovule the female gametophyte shows free nuclear division, while the youngest is in the enlarging megaspore stage. $\times 16$, red. $\frac{1}{2}$.

Fig. 59. Strobilus with four bracts, of which two are fertile; the laminae are barely indicated, but the bases have swollen to a large size, and are of a bright red colour; the ovules are in the prefertilization stage, the peripheral half of the integument showing lignification of the cells.

Fig. 6o. P. Hallii. Strobilus with bases of bracts swollen and red in colour, one bract being fertile; the ovule is in young embryo stage. $\times 8$, red. $\frac{1}{2}$.

Fig. 6I. Strobilus in which the bract bases have remained unmodified; one bract is fertile, with ovule in young embryo stage. $\times 8$, red. $\frac{1}{2}$.

Fig. 62. Longitudinal section of a strobilus with three unmodified bracts, the upper one fertile; the ovuliferous scale shows stone-cell thickening in the mesophyll and very large resin canals, also phloem strand penetrating the integument; the integument is entirely lignified, with the exception of a few cell layers in proximity to the nucellus, which is mostly digested by the prothallus; the latter is surrounded by a well-developed megaspore membrane and contains a young embryo. $\times 16$, red. $\frac{1}{2}$.

Fig. 63. Strobilus with two fertile bracts. Nat. size.

\section{PLATE LII.}

Fig. 64. Strobilus with bract bases unmodified and shorter than the ovule.

Fig. 65. P. nivalis, showing a strobilus with three bracts, still undifferentiated, one of the lower bracts being fertile; the strobilus is in the axil of a foliage leaf of the axis. $\times 8$.

Fig. 66. Strobilus with two undifferentiated bracts, one of which is fertile; the ovule is in the pollination stage. $\times 8$.

Fig. 67. Strobilus with two bracts, one of which is fertile; enlarging macrospore stage. $\times 8$. 
Fig. 68. Strobilus with three bracts, two of which are fertile ; macrospore stage with dividing nuclei. $\times 8$.

Fig. 69. Strobilus with three bracts, one of which is fertile; the lamina of the bracts are reduced to points, while the bases are much swollen and of a bright red colour; young embryo stage. $\times 8$, red. $\frac{1}{2}$.

Fig. 70. Strobilus with two bracts, both unmodified; ovule in young embryo stage. $\quad \times 8$, red. $\frac{1}{2}$.

Fig. 7 I. Strobilus with three bracts; the lamina of one bract with an undeveloped ovule is dead. $\times 8$, red. $\frac{\mathrm{I}}{2}$.

\section{PLATE LIII.}

Sections cut $2-3 \mu$ on a Minot microtome.

Fig. 72. P. vitiensis. Transverse section through an ovule in the pollination stage, taken below the base of the nucellus, where the four bundles of the scale break up into branches which run down the lamina of the same (Fig. I7). In this case eight branches can be counted; the integument shows a thick ring of tannin and starch cells, the walls of which are becoming lignified. This ring is seen penetrated in two places by phloem strands from the vascular system (Fig. I 7). The tannin cells surrounding the base of the nucellus are seen in the integument, which is limited by an epidermal layer of tannin cells. Similar cells mark the peripheral layer of the nucellus, which is bounded on the inside by the tapetum in which lies the dividing macrospore. $\times \mathbf{2 4}$.

Fig. 73. Transverse section, same series, taken through the micropyle and the base of the ovuliferous scale, just above the apex of the nucellus where the four bundles have again approximated. $\times 25$.

Fig. 74. P. spicata. Longitudinal section of nucellus only, showing the well-marked tapetum, megaspore membrane, and free cell formation in the prothallus. $\times$ I 20.

Fig. 75. Longitudinal section of ovule, showing zone of stone cells (torn) in the ovuliferous scale, with the zone of tannin and starch cells lining the integument and the nucellus. The cells at the apex of the nucellus contain starch and show some pollen-tubes; on the inside the nucellus is limited by the tapetum. The prothallus is very much contracted, but the megaspore membrane can be traced folding in and out with the prothallial tissue, which shows cell-wall formation. $\times 45$.

Fig. 76. P. ferruginea, longitudinal section of young strobilus in the stage of Fig. 25. It shows an undifferentiated nucellus with basal cell growth and a limiting layer of tannin cells to the nucellus and the free portion of the integument; in the ovuliferous scale the tannin cells at this stage are limited to the epidermis and two or three hypodermal layers. $\times 27$.

Fig. 77. Transverse section through the nucellus, integument, and bract bases of the same stage. The two vascular bundles are seen with the xylems converging, whereas in the apex of the scale the phloems face each other. This rotation finally leads to a normal orientation as the bundle slips into its place in the ring of leaf-traces in the strobilus. $\times 4^{2}$.

Fig. 78. P. neriifolia. Longitudinal section of strobilus in pollination stage (Fig. 49), showing a very attenuated ovuliferous scale; a well-marked tapetum is seen in the nucellus, enclosing the enlarging megaspore. $\times 7$.

Fig. 79. P. elata. Longitudinal section of strobilus with undifferentiated nucellus (Fig. $3 \mathrm{I}$ ), showing modified bracts with swollen bases, proliferation of mesophyll tissue; also the independence of the vascular system of the fertile scale and the sterile bract at the base of the strobilus, indicated by the two resin canals far apart. $\times 26$.

Fig. 80. Transverse section of strobilus in above stage, taken at the apex of the nucellus, showing lamina of the fertile bract. Slightly oblique. $\times 40$.

Fig. 8I. P. nivalis. Transverse section of an ovuliferous scale taken across the micropyle, showing the foliar structure of the scale. $\times 45$. 
Annats of Botany,

4

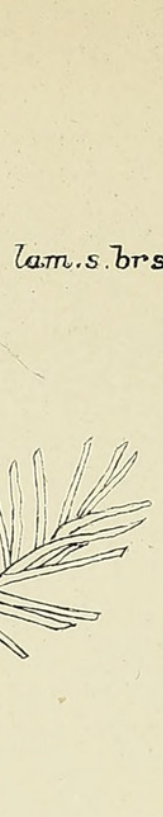

1.

s.t. strob.

$b r: b s$

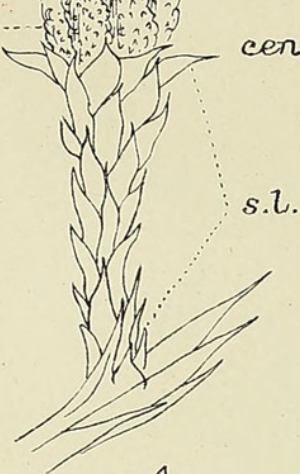

4.

Zam f. br:

. Tam.f.br idio.

r.c.

e... !

m.m...

arch

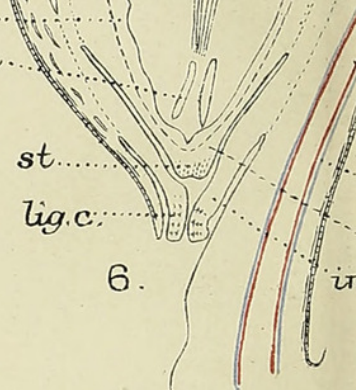

exp. 2.
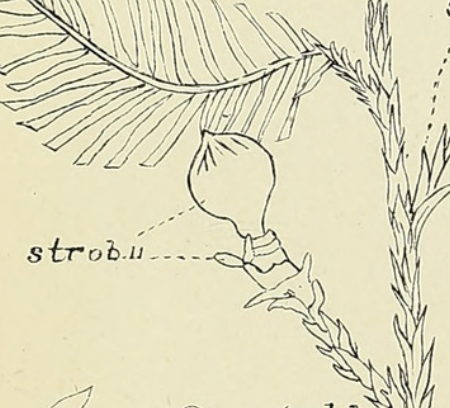

av zamf.br

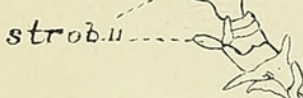

(r)


2 .

stom. tra.

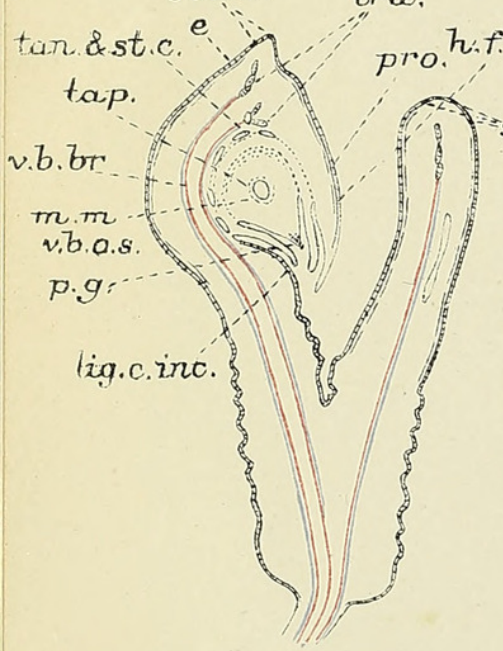

9.

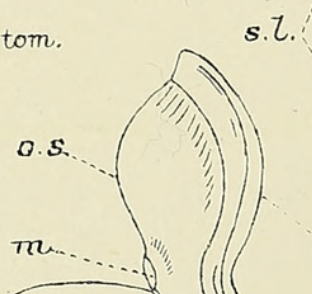

s.l.

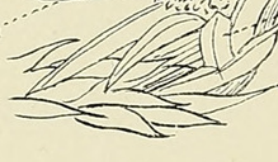

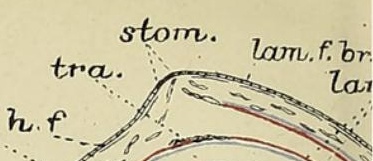
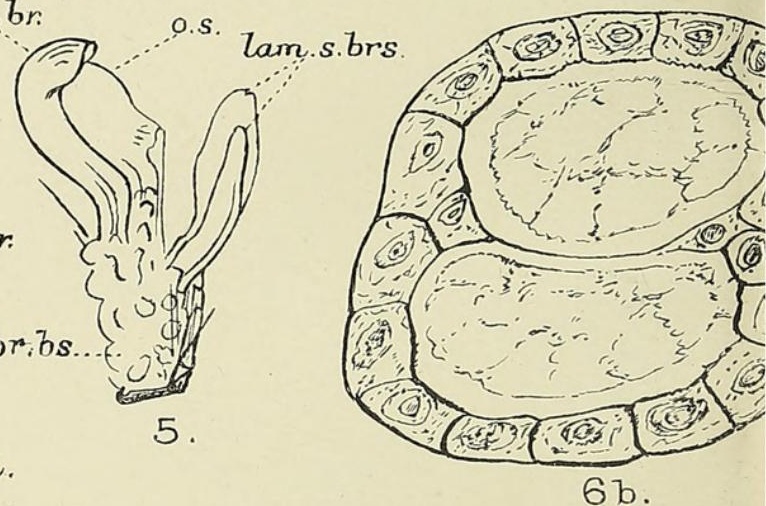

5.

$6 \mathrm{~b}$.
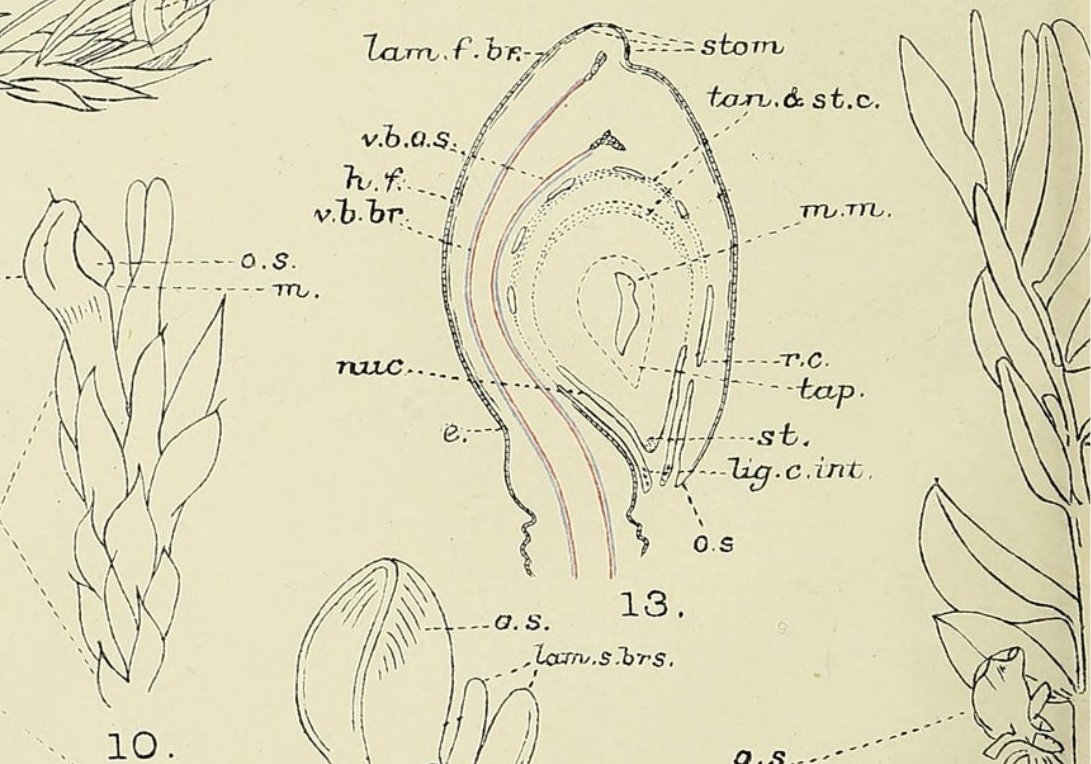

Lasn surs.

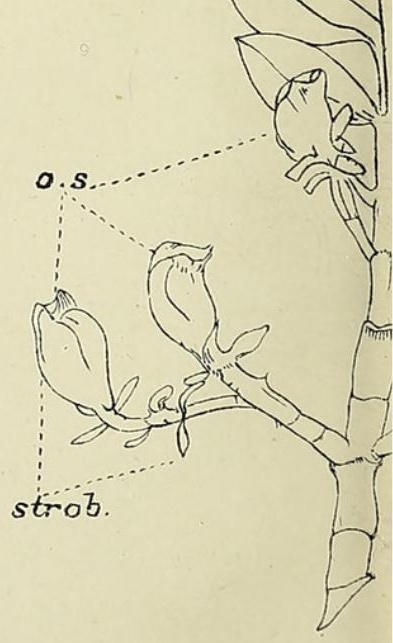

L.S.G. del.

11.

iarn

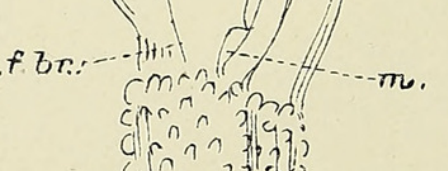

or bs chn?

ân $n$ त्?

12. 4 . 


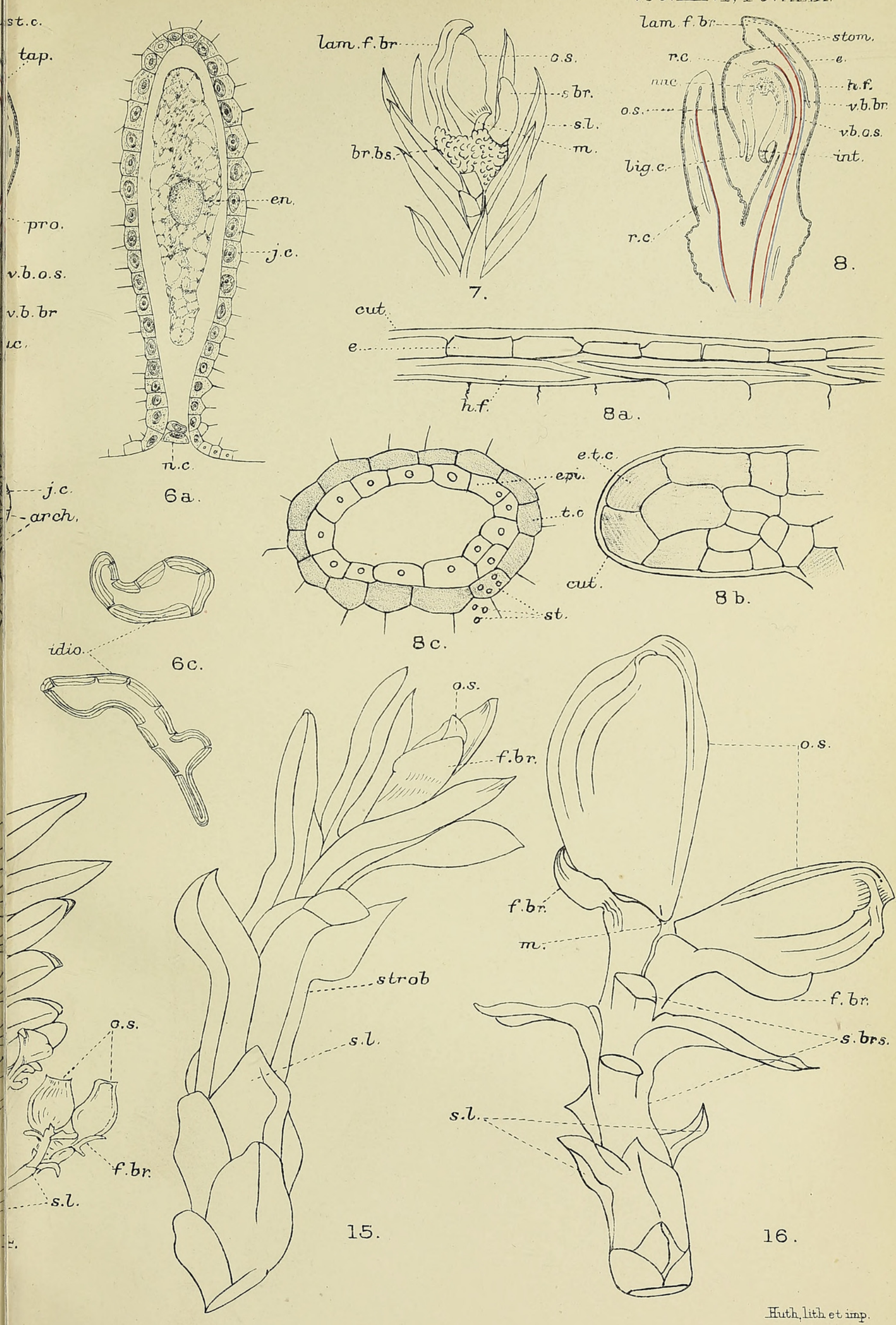


Annals of Botany

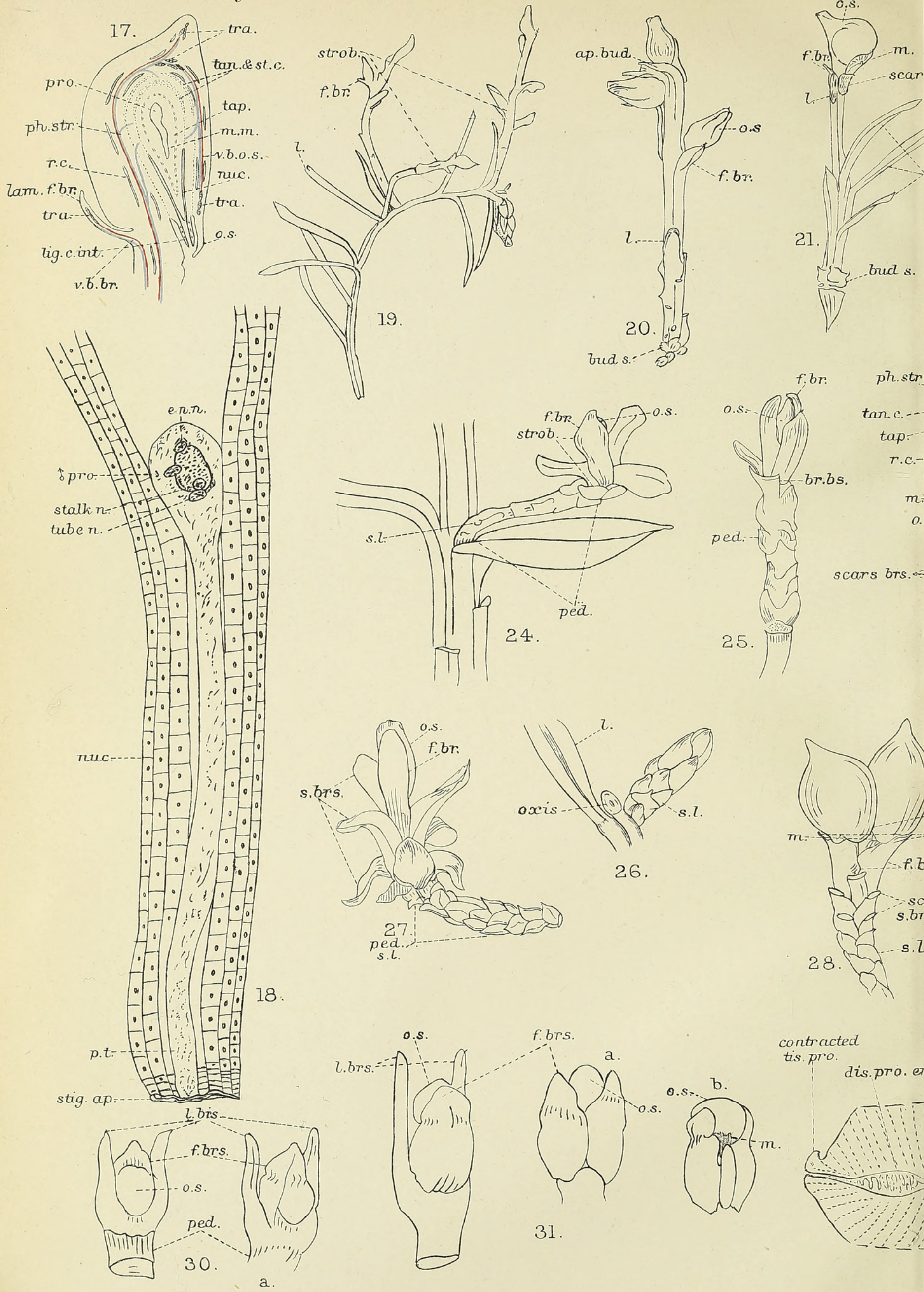




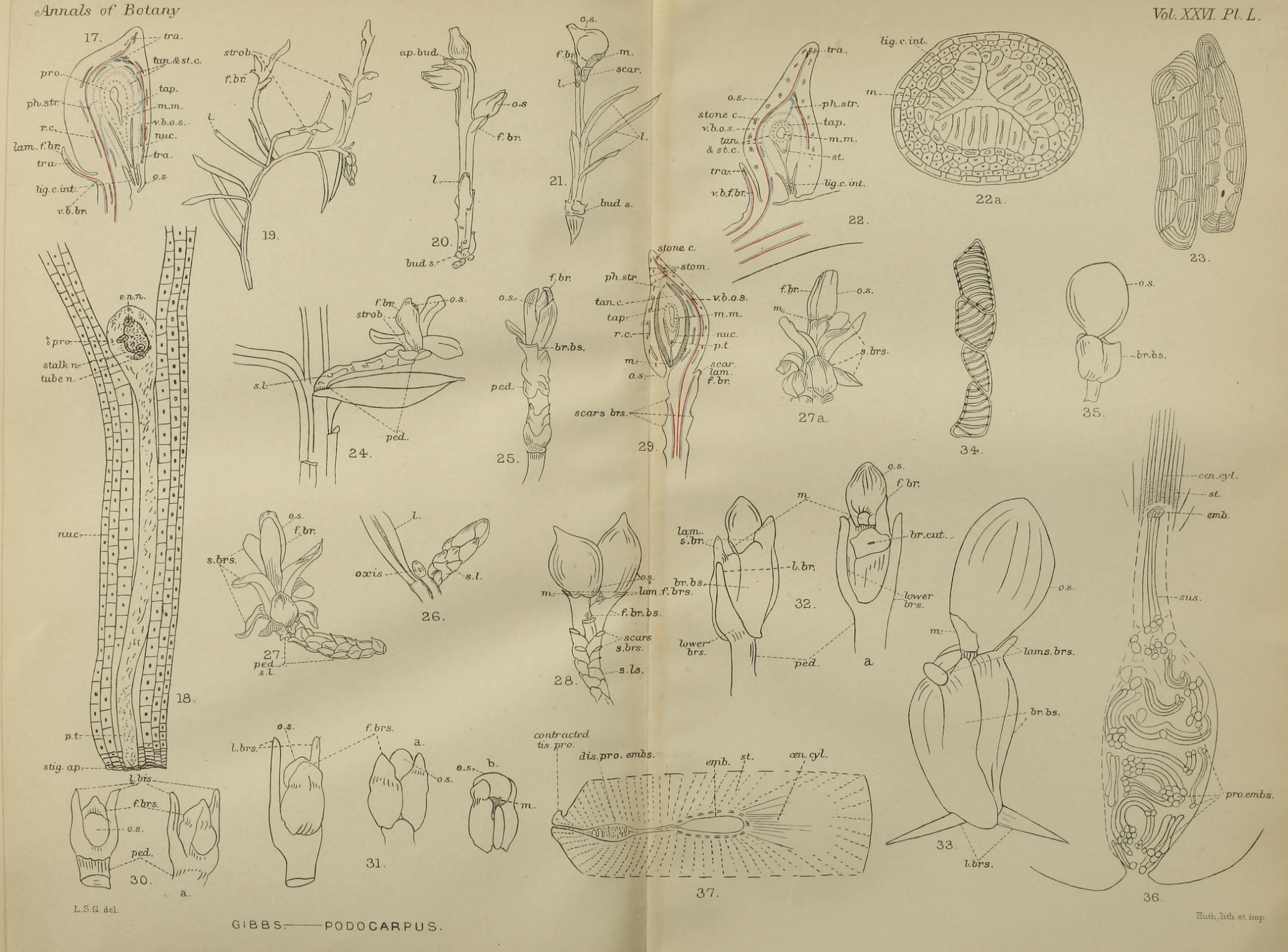



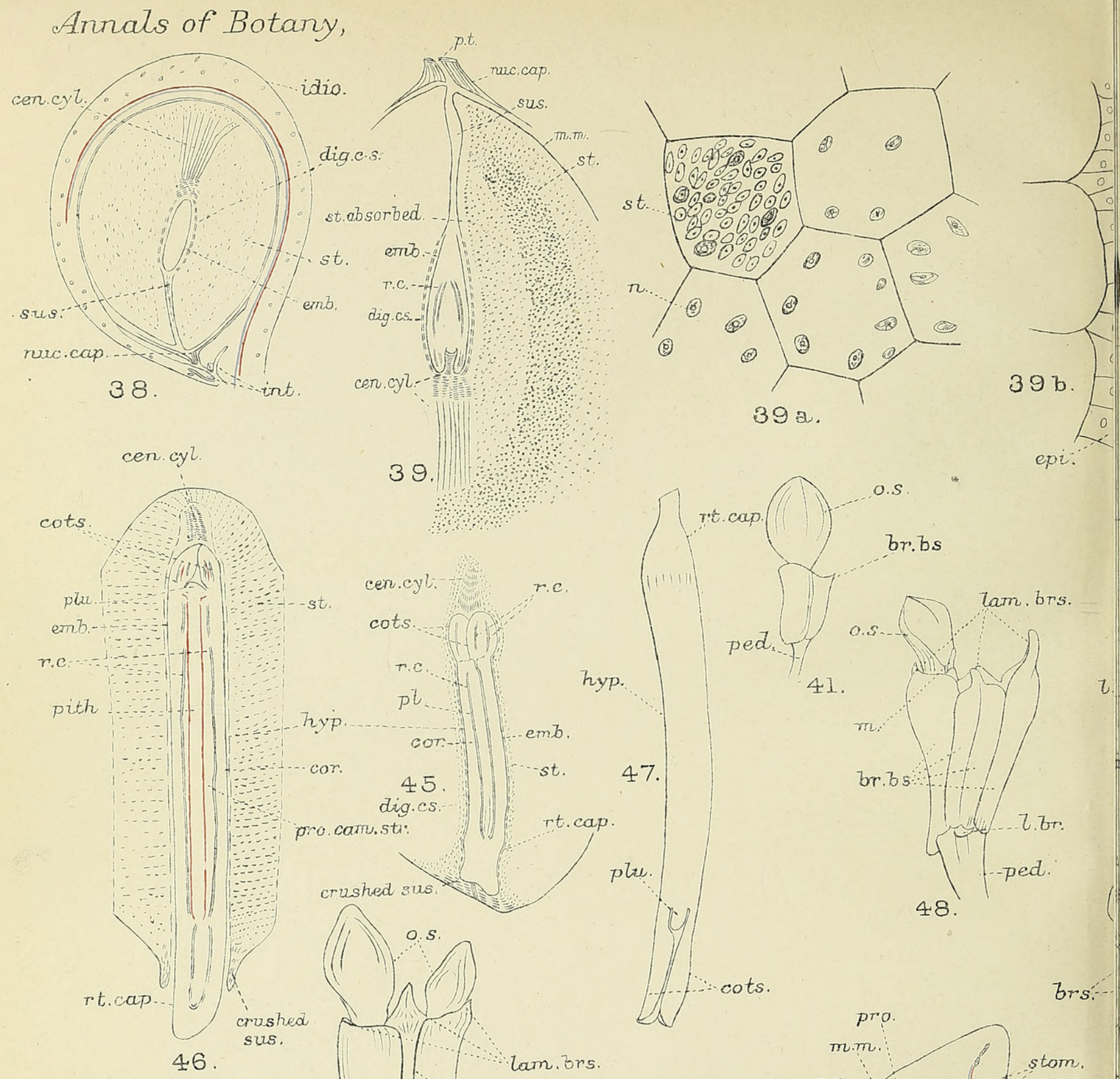

39.

39 a.
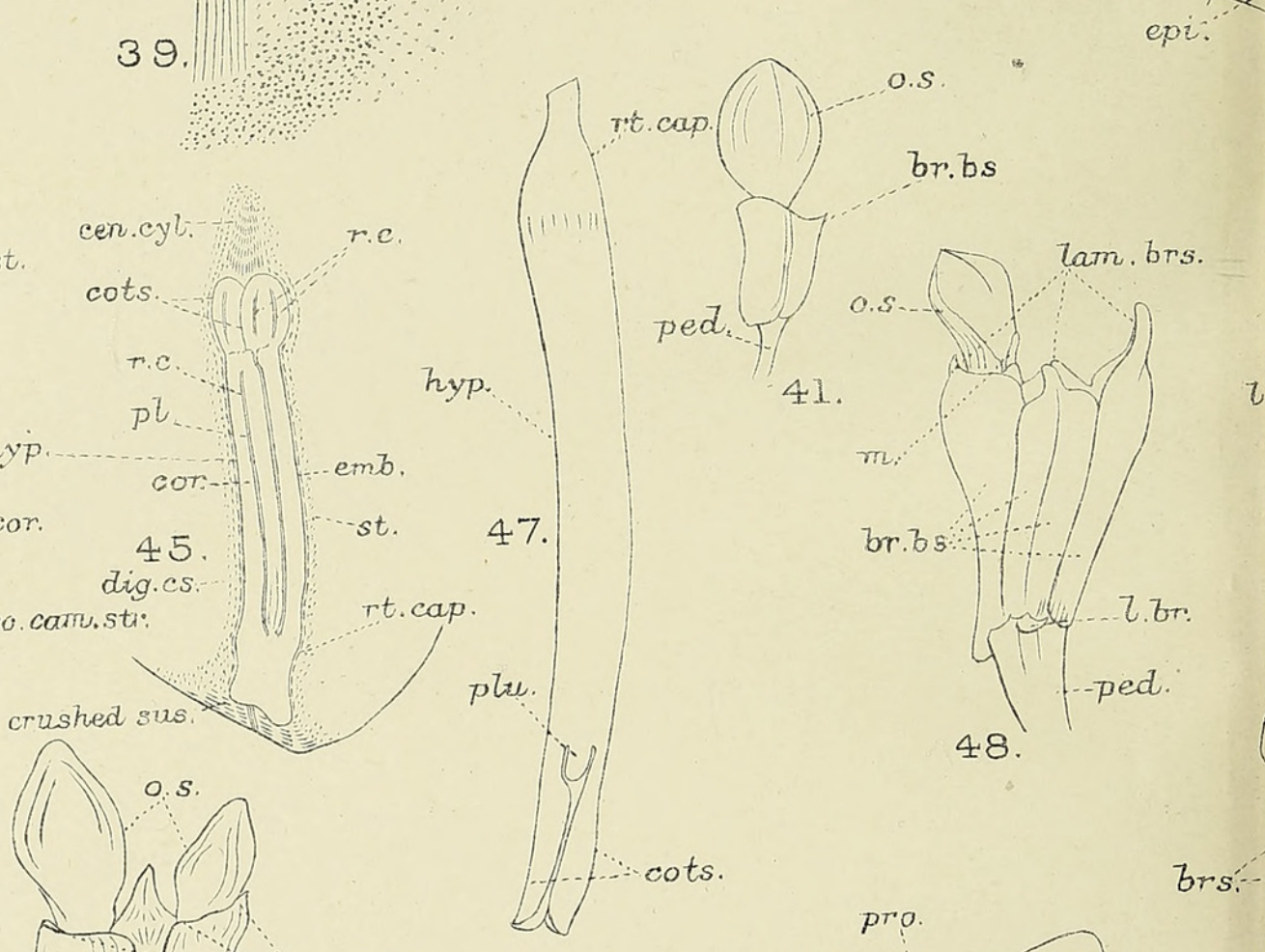

48.

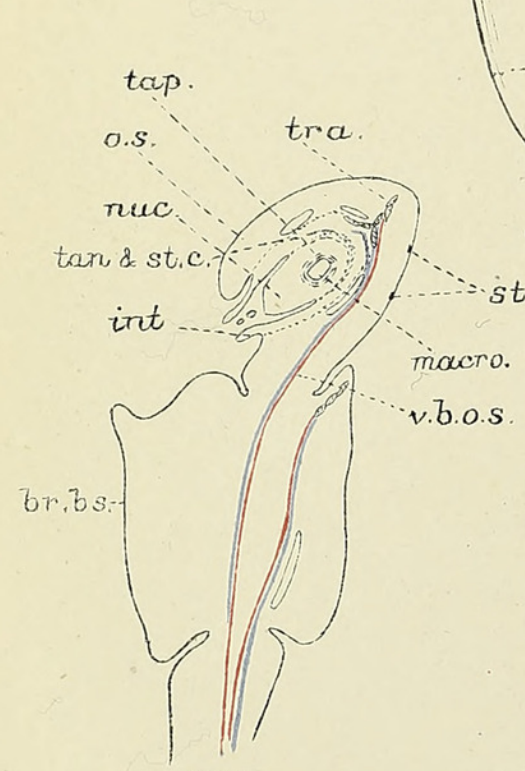

57.

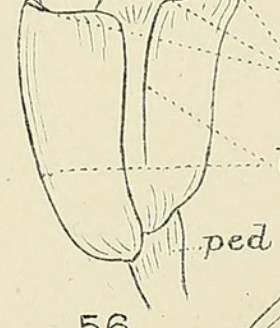

tam.ors.

56.

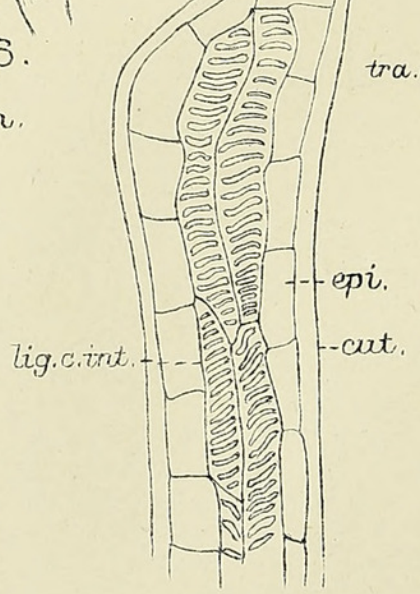

$57 \mathrm{a}$.

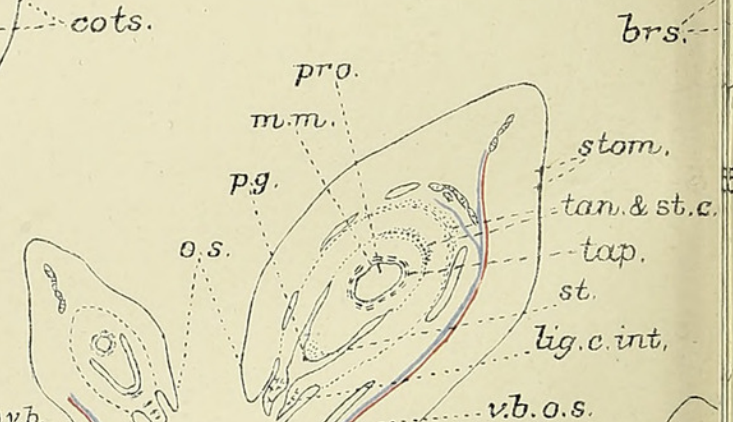

L.S.G. del 
Annats of Botany,
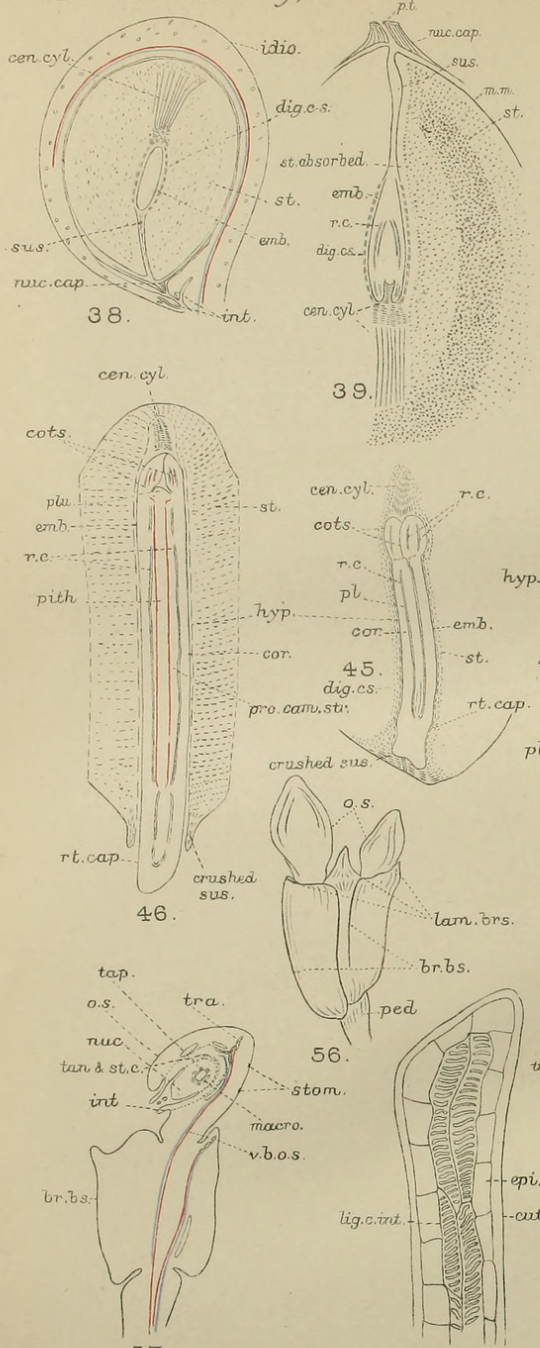

57.

(it)
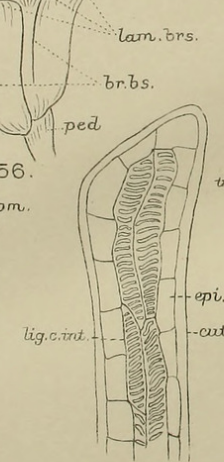

$57 \mathrm{a}$.
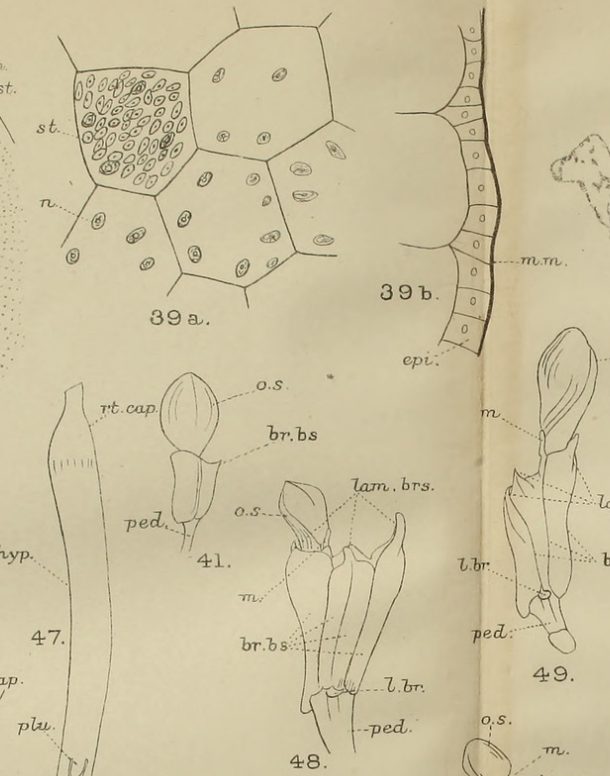

$39 \mathrm{a}$.

cots.
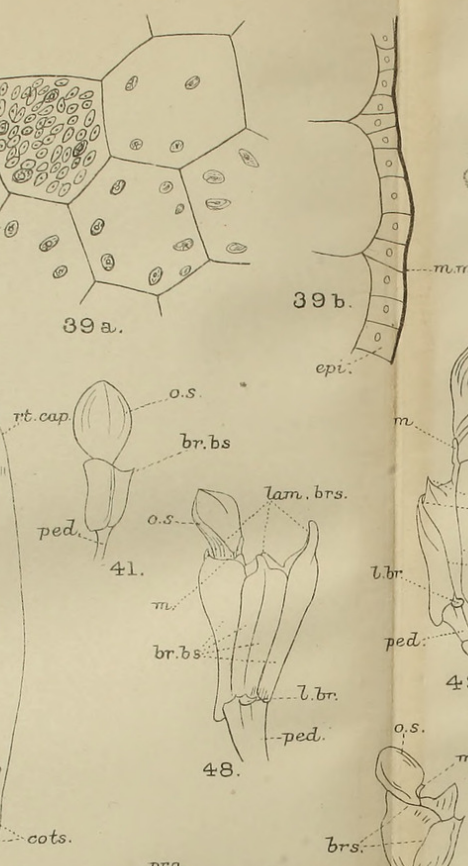

bras.
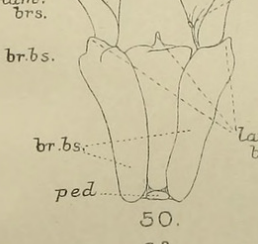

o.s.
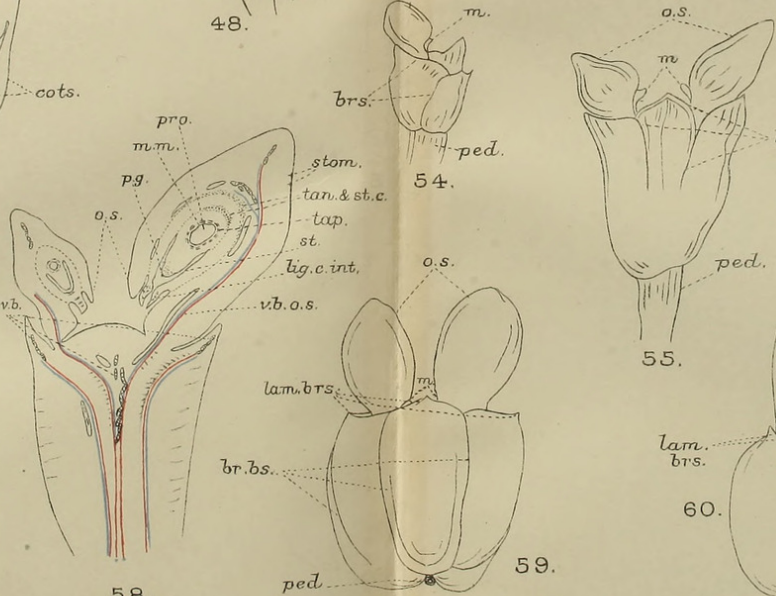

Vol.XXVI. PL.II.

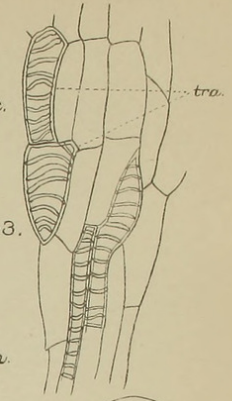

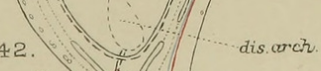

st... $\cdots$ int
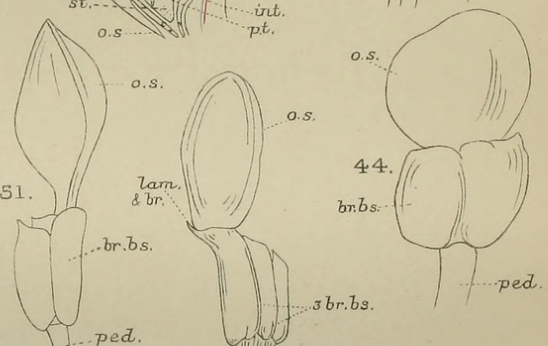

-..ped. U.ilify

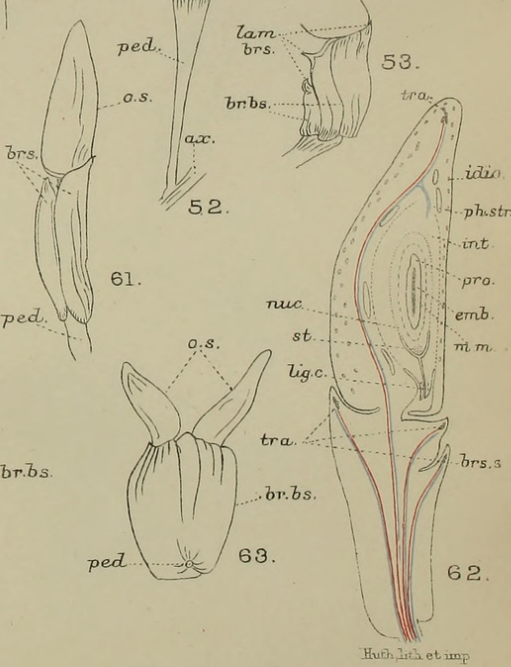

GIBBS - PODOCARPUS 
Anrals of Botany

Vol. XXVI.Pl.LII.





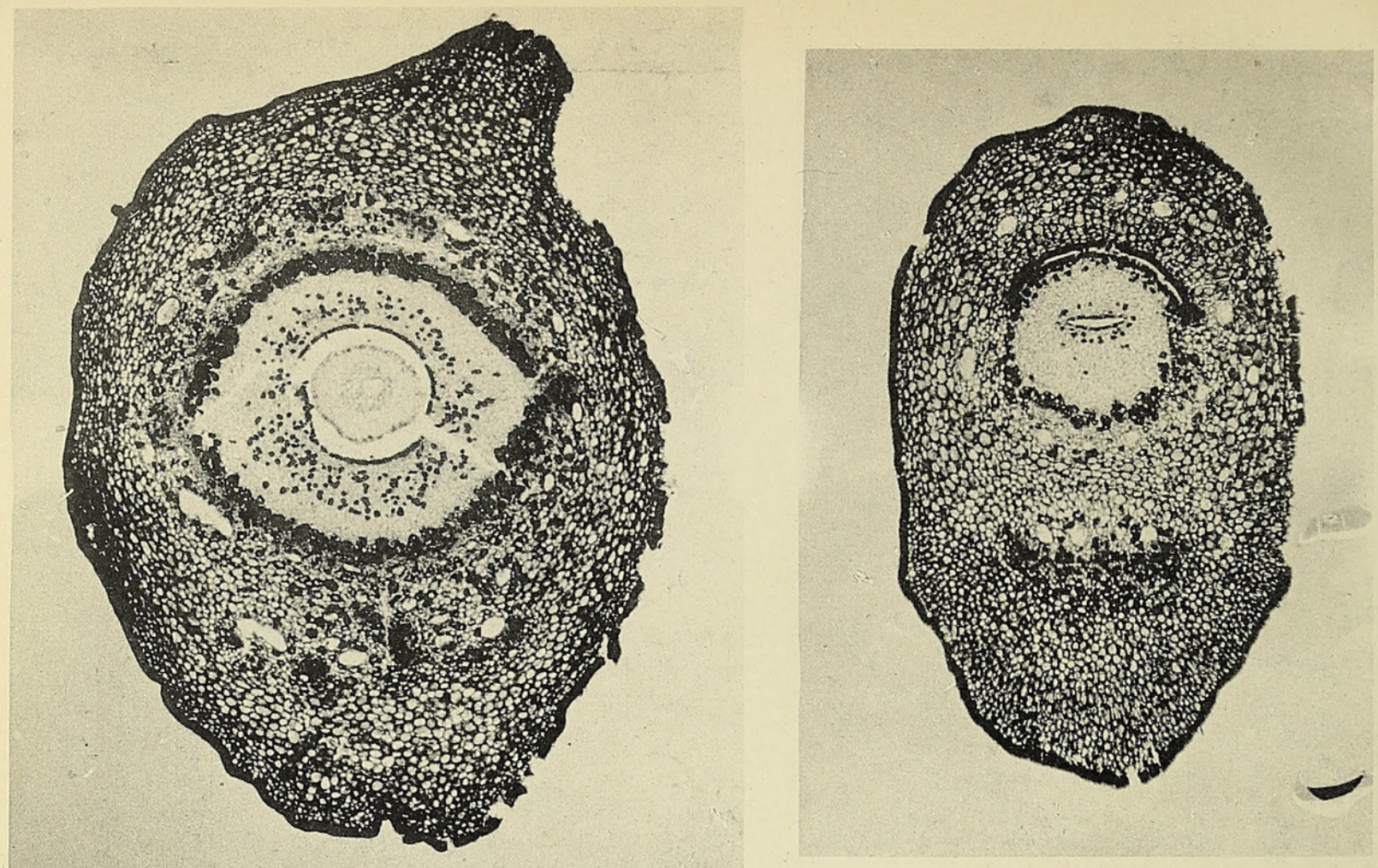

73.

Vol.XXVI. Pl.LIII.
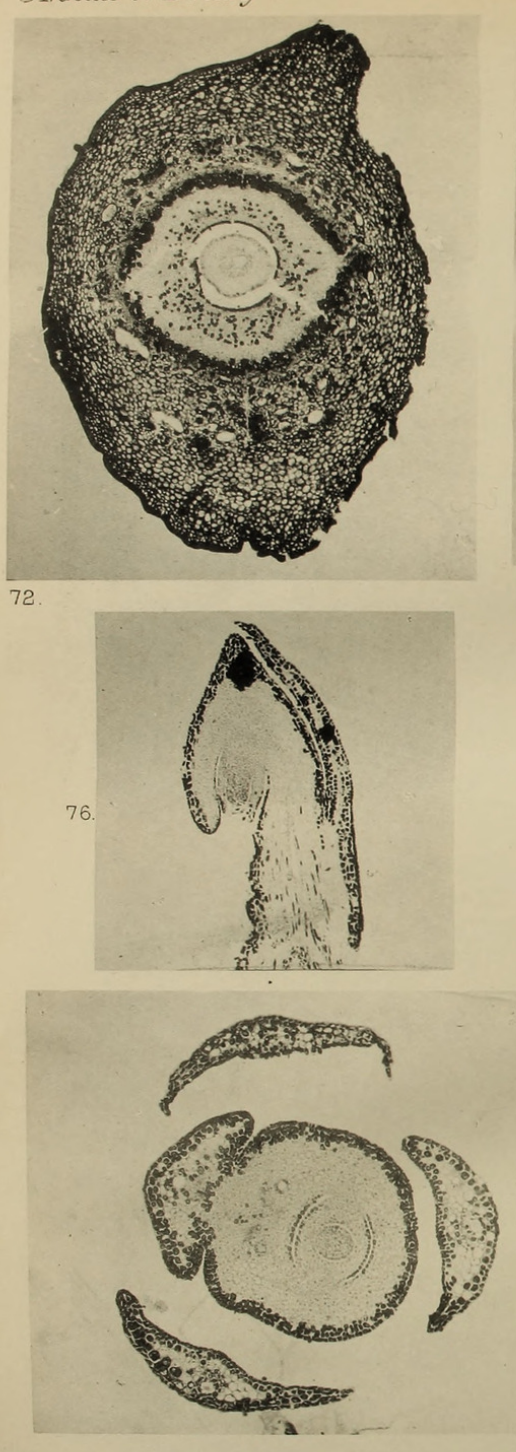

GIBBS:- PODOCARPUS

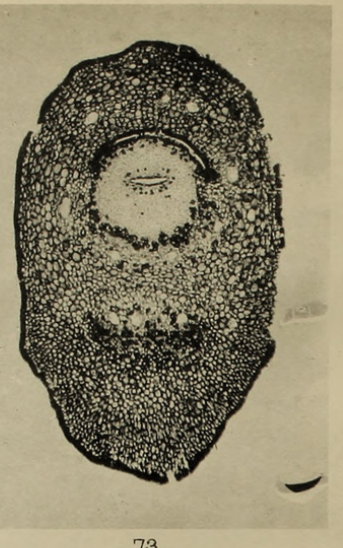

73



78
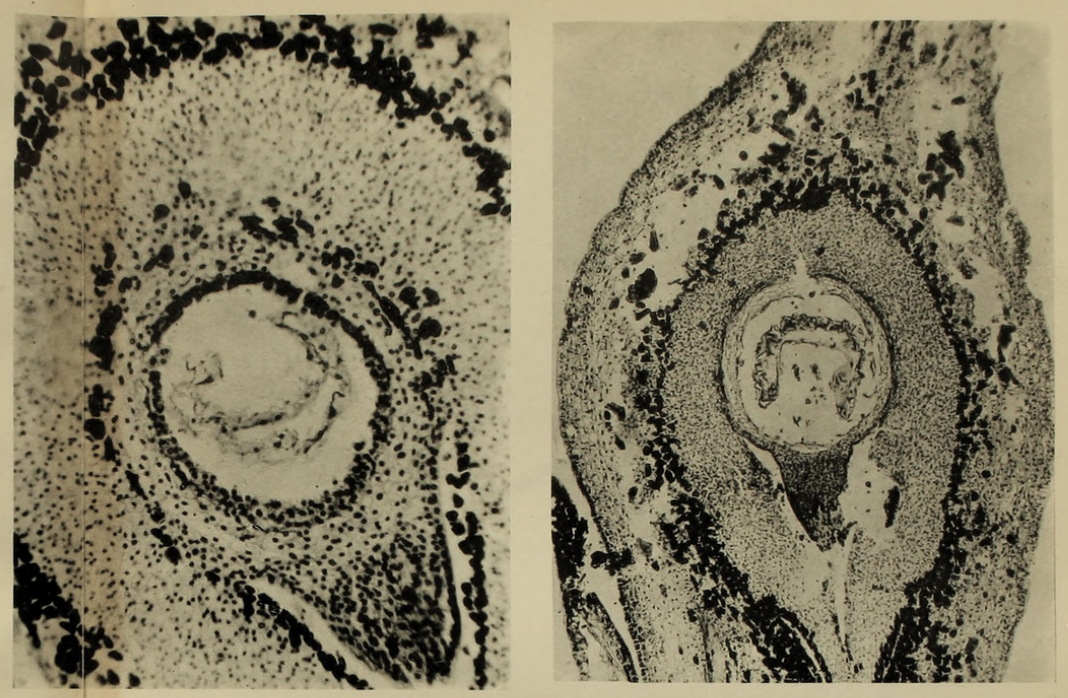

80.
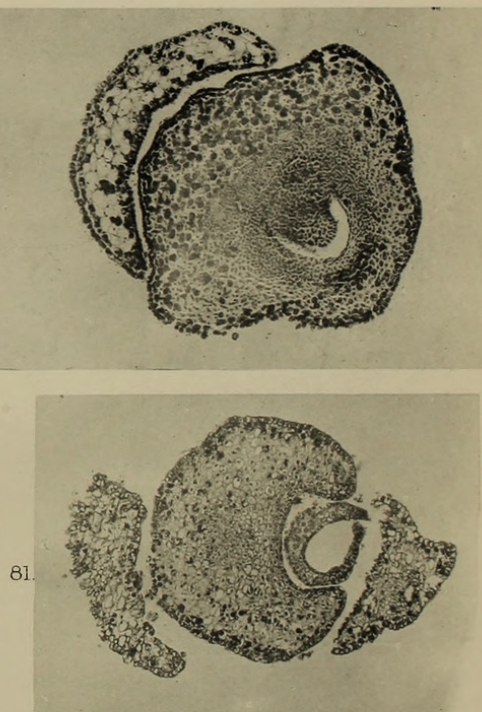


\section{$2 \mathrm{BHL}$ Biodiversity Heritage Library}

Gibbs, Lilian S. 1912. "On the development of the female strobilus in Podocarpus." Annals of botany 26, 515-571.

https://doi.org/10.1093/oxfordjournals.aob.a089400.

View This Item Online: https://www.biodiversitylibrary.org/item/236773

DOI: https://doi.org/10.1093/oxfordjournals.aob.a089400

Permalink: https://www.biodiversitylibrary.org/partpdf/319914

\section{Holding Institution}

Smithsonian Libraries

\section{Sponsored by}

Biodiversity Heritage Library

\section{Copyright \& Reuse}

Copyright Status: Not in copyright. The BHL knows of no copyright restrictions on this item.

This document was created from content at the Biodiversity Heritage Library, the world's largest open access digital library for biodiversity literature and archives. Visit BHL at https://www.biodiversitylibrary.org. 